IZA DP No. 5917

Access to Justice and Entrepreneurship:

Evidence from Brazil's Special Civil Tribunals

Guilherme Lichand

Rodrigo R. Soares

August 2011 


\title{
Access to Justice and Entrepreneurship: Evidence from Brazil's Special Civil Tribunals
}

\author{
Guilherme Lichand \\ Harvard University \\ Rodrigo R. Soares \\ Pontifical Catholic University of Rio de Janeiro \\ and IZA
}
Discussion Paper No. 5917
August 2011

IZA

P.O. Box 7240

53072 Bonn

Germany

Phone: +49-228-3894-0

Fax: +49-228-3894-180

E-mail: iza@iza.org

\begin{abstract}
Any opinions expressed here are those of the author(s) and not those of IZA. Research published in this series may include views on policy, but the institute itself takes no institutional policy positions.

The Institute for the Study of Labor (IZA) in Bonn is a local and virtual international research center and a place of communication between science, politics and business. IZA is an independent nonprofit organization supported by Deutsche Post Foundation. The center is associated with the University of Bonn and offers a stimulating research environment through its international network, workshops and conferences, data service, project support, research visits and doctoral program. IZA engages in (i) original and internationally competitive research in all fields of labor economics, (ii) development of policy concepts, and (iii) dissemination of research results and concepts to the interested public.
\end{abstract}

IZA Discussion Papers often represent preliminary work and are circulated to encourage discussion. Citation of such a paper should account for its provisional character. A revised version may be available directly from the author. 


\section{ABSTRACT}

\section{Access to Justice and Entrepreneurship: Evidence from Brazil's Special Civil Tribunals*}

Entrepreneurship is usually identified as an important determinant of aggregate productivity and long-term growth. The determinants of entrepreneurship, nevertheless, are not entirely understood. A recent literature has linked entrepreneurship to the development of the justice system. This paper contributes to this literature by evaluating the role of access to justice in determining the incidence of entrepreneurship. We explore the creation of Special Civil Tribunals in the Brazilian state of São Paulo during the 1990s. Special Civil Tribunals increased the geographic presence of the justice system, simplified judicial procedures, and increased the speed of adjudication of disputes. Using census data, and difference-indifferences and instrumental variable strategies, we find that implementation of Special Civil Tribunals led to increased entrepreneurship, defined as the probability that individuals are employers or self-employed. Results are particularly strong and robust for the case of selfemployment, and do not seem to be related to other changes in infrastructure or public good provision at the local level, or to pre-existing trends in entrepreneurship.

JEL Classification: K1, K41, K42, H41, O12, O17, O54

Keywords: $\quad$ access to justice, courts, entrepreneurship, institutions, Brazil

Corresponding author:

Rodrigo R. Soares

Departamento de Economia

Pontifícia Universidade Católica do Rio de Janeiro

Rua Marquês de São Vicente, 225 - Gávea

22451-900 Rio de Janeiro, RJ

Brazil

E-mail: soares@econ.puc-rio.br

\footnotetext{
* This paper benefited from comments from Claudio Ferraz, Gabriel Madeira, and seminar participants at PUC-Rio and the 2010 Meetings of the Latin American and Caribbean Economic Association (Medellín, Colombia).
} 


\section{Introduction}

Entrepreneurship is usually indentified as an important determinant of aggregate productivity and long-term growth (Banerjee and Newman, 1993 and Aghion and Bolton, 1997). The determinants of entrepreneurship, nevertheless, are not entirely understood. A recent literature has linked entrepreneurship to the development of the justice system, paying particular attention to judicial quality as a determinant of access to credit, formality, and willingness to start a venture (see, for example, Visaria, 2009, Quintin, 2008, Chemin, 2009a and 2009b). By securing property rights and enforcing contracts, the justice system guarantees that future returns to private investments are appropriated and promises of future payments are fulfilled. These guarantees constitute commitment devices that foster the development of explicit and implicit credit markets and increase the return to entrepreneurial activities.

This paper contributes to this literature by exploring an institutional change that increased the geographical availability of a low-cost judicial technology. We use this episode to evaluate the impact of access to justice on entrepreneurship. Specifically, we explore a unique experience of creation of Special Civil Tribunals in the Brazilian state of São Paulo during the 1990s. Special Civil Tribunals increased the geographic presence of the justice system in municipalities, simplified judicial procedures, and increased the speed of adjudication of disputes (particularly through facilitation of agreements in early stages of the process). We find that implementation of Special Civil Tribunals was correlated with increased entrepreneurship, defined as the probability that individuals are occupied as employers or self-employed.

Analyses of the role of institutions in general, and the justice system in particular, face two traditional challenges: endogeneity and omitted variables. Wealthier and more dynamic areas are able to afford and may demand better justice systems. And areas with better justice systems may have more developed institutions also in other relevant dimensions. We deal with these potential problems by exploring the institutional change represented by the creation of Special Civil Tribunals. Special Civil Tribunals have competency to judge actions of smaller complexity (up to 40 minimum wages) concerning micro-enterprises, consumer rights, debt execution, neighborhood conflicts, torts, etc. They have authority to execute extrajudicial warranties - that is, debt contracts enforceable out of court - and also to execute their own decisions (Cunha, 2008). The introduction of these new courts in Brazil was perceived as 
constituting "the creation of a new justice, different from all others, simple, agile, safe and effective" (Tourinho Neto and Figueira Júnior, 2007, p. 69, translated by the authors), overcoming what local legal authors termed "constrained litigiousness."

Using census data from the state of São Paulo between 1970 and 2000, we apply difference-in-differences and instrumental variable strategies to evaluate whether entrepreneurship increased more rapidly in areas that received Special Civil Tribunals. Our main results indicate that implementation was associated with an increase of 3.9 percentage points in entrepreneurship (3.7 for self-employment and 0.4 for employers), as compared to an initial level of $27 \%$ in 1970 ( $25 \%$ for self-employed and $2 \%$ for employers). The evidence also indicates that the increase in entrepreneurship was particularly strong for individuals above the median level of schooling. Considering that educational attainment is highly correlated with wealth, we understand this result as indicating that marginal individuals - those for which the change was enough to foster a transition towards entrepreneurial activities - were those in the upper half of the socioeconomic strata. Our results are particularly strong and robust for the case of selfemployment, and do not seem to be related to other changes in infrastructure or public good provision at the local level, nor to pre-existing trends in entrepreneurship. ${ }^{1}$ Results are very similar, but slightly stronger, when we instrument the implementation of Special Civil Tribunals with an interaction between the timing of approval of the law and a judicial characteristic closely related to adoption (housing the headquarter of a judiciary district). Overall, the evidence indicates that the decision to become an entrepreneur is positively affected by the availability of a low-cost litigation technology.

The literature on institutions and growth has documented that, after controlling for broader property right measures, narrower contracting institutions play no role in explaining differences in economic development across countries (Acemoglu and Johnson, 2005a and 2005b). ${ }^{2}$ Nonetheless, recent within country work exploring institutional changes has revealed a vast amount of evidence on the impact of judiciary efficiency on the development of credit

\footnotetext{
${ }^{1}$ Historically, self-employment in Brazil has been particularly common among low-skill workers. This pattern seems to be changing in the recent past. The evidence suggests that increased access to justice may have been partly responsible for this change.

${ }^{2}$ Still, within Brazil, Naritomi, Soares, and Assunção (2009) instrumented the presence of courts in municipalities with historical variables and found it to be significantly related to long-term development.
} 
markets, entrepreneurship, and economic activity. ${ }^{3}$ Visaria (2009) considers the effects of the creation of Debt Recovery Tribunals (DRTs) in India. From 1993 to 1999, DRTs were introduced as the institutional arena for legal disputes between banks and borrowers. Visaria (2009) takes advantage of their staggered adoption across Indian states in order to assess their impact on delinquency rates and interest rates, documenting a negative significant effect on both dimensions. ${ }^{4}$ Also for India, Chemin (2009b) investigates the impact of judiciary efficiency on development by looking at amendments to the Code of Civil Procedures that affected judicial ambiguity and complexity. Using data from 1971 to 1996, he shows that exogenous increases in trial duration have negative impact on farmers, particularly those with lower collateral. The paper also documents a negative effect of longer trials on credit and manufacturing output.

The work of Chemin (2009a) is the closest in spirit to our paper. Exploring a judicial reform in Pakistan that intended to decrease the backlog of court cases by teaching case-flow management techniques to judges, the author explores a difference-in-differences strategy to evaluate the impact of the reform on judicial efficiency. Following, he looks at the impact of increased judicial efficiency on demand for credit, on steps taken to open a business, and on transition probabilities from unemployment to entrepreneurship. The main results are that judges in affected areas disposed significantly more cases, and that the reform had a positive impact on investment confidence, on demand for credit, and on transition probabilities to entrepreneurship.

Our paper differs from previous contributions in two ways. First, we explore the expansion of the technology of Special Civil Tribunals, which reduced the cost of access to the justice system. Other papers analyze institutional changes within a given geographic distribution of the branches of the justice system, not exploring explicitly the issue of cost of access. Second, whereas Chemin (2009a) analyzes the transition of individuals from unemployment or salaried work into entrepreneurship by looking at individuals' willingness to start a venture, we draw upon household-level data to explore the actual and overall incidence

\footnotetext{
${ }^{3}$ There are also other papers using calibration exercises, cross-country data, or exploring within country variation not explicitly related to specific institutional changes, that reach similar conclusions. See, among others, Japelli et al (2005), Laeven and Woodruff (2007), Antunes et al (2008), Quintin (2008), and Casas-Arce and Saiz (2010). In the text, we concentrate the review on the papers most closely related to ours in terms of strategy and objective.

${ }^{4}$ Liliendfeld-Toal et al (2009) consider the possibility of an adverse impact of this same reform, through an increase in interest rates due to general equilibrium effects. Evidence based on firm-level panel data reveals that small firms experienced contraction in borrowing and fixed assets, while the opposite was observed for large firms.
} 
of entrepreneurship in the population. So our specific contribution is to assess the impact of increased access to the justice system on the incidence of entrepreneurship. ${ }^{5}$ Moreover, we conduct some exploratory analysis in an attempt to track down the main mechanisms linking access to justice to entrepreneurship, by looking at the heterogeneity of responses according to initial credit availability and capital intensity across areas and sectors. The evidence suggests that the increase in entrepreneurship following the introduction of SCTs was primarily driven by the reduced risk of expropriation of physical assets, rather than increased availability of finance.

The remainder of the paper is structured as follows. Section 2 describes in detail the previous institutional setting and the reform that instituted Special Civil Tribunals. Section 3 describes the data and our empirical strategy. Section 4 presents the results. Finally, section 5 concludes the paper.

\section{Special Civil Tribunals}

The origin of Special Civil Tribunals in Brazil dates back to the 1988 constitution, which had as a major concern the broadening of fundamental rights and the design of adequate public goods delivery mechanisms. Although equity in access to justice has been a constitutional principle since the early $19^{\text {th }}$ century, it was seen merely as a formal principle rather than as a guideline to policy implementation, having in the labor justice its sole exception (Carneiro, 2003). According to Carneiro (2003, p.41, translated by the authors), for "the remaining branches of process law, and especially civil law (...), until the 1980s the practice of our tribunals remained individualistic (...) [and] elitist (...)." Individualistic because it was based on the principle of formal equity, but there was no real concern in relation to the effective access of the larger part of the population. And elitist because it was "expensive, distant, mysterious and unknown, a true arena where the richer, better prepared and with better lawyers, obtained more positive results" (Carneiro, 2003, p.41, translated by the authors).

The 1988 constitution determined the creation of special tribunals to judge and execute civil actions of smaller complexity, with emphasis on procedural simplicity (Carneiro, 2003).

\footnotetext{
${ }^{5}$ For the case of Brazil, some papers have analyzed the impact of the judicial system and contract enforcement on economic outcomes: Castelar (2000) provides an informal overview of the relationship between the judiciary and the Brazilian economy; Costa and De Mello (2008) and Coelho, Funchal and De Mello (2010) investigate the effects of payroll lending on interest rates and credit volume, showing that better protection against default increases lending while decreasing borrowing costs; and Madeira, Rangel and Rodrigues (2010) find that payroll lending has a positive effect on entrepreneurship.
} 
These principles were materialized in the 9.099/1995 law that created the Special Civil Tribunals (Juizados Especiais Cíveis), from now on SCTs. SCTs were eventually regulated by state laws following the federal one, leading to the actual implementation of the tribunals throughout the 1990s.

SCTs have the competency to judge actions of smaller complexity (up to 40 minimum wages, roughly US\$14,000 at the current minimum wage and exchange rate) concerning consumer rights, debt execution, neighborhood conflicts, torts, etc. Law 9.099/1995 authorized the execution of extrajudicial titles, ${ }^{6}$ made mandatory the presence of lawyers for actions between 20 and 40 minimum wages and, most importantly, determined SCTs competency to execute their own decisions (Cunha, 2008). Moreover, in 1999, law 9.841/1999 extended SCTs' competencies to included micro-firms, which from that date on could file complaints under the small claims' technology. In contrast, SCTs do not judge actions related to family law, labor justice, or bankruptcy.

Tourinho Neto and Figueira Júnior (2007) notice that: "Regarding the 9.099/1995 law as a simple procedural norm is the major and most serious mistake one can make, since (...) its scope (...) [concerns] the creation of a new justice, different from all others, simple, agile, safe and effective" (Tourinho Neto and Figueira Júnior, 2007, p.69, translated by the authors). As a response, the number of actions increased sharply after the installation of SCTs, overcoming what local legal authors usually term "constrained litigiousness." In São Paulo in 1999, one year after the creation of most Special Civil Tribunals in the state, $6.15 \%$ of total judicial actions (15.4\% of the civil ones) were handled within the new system, while already by 2003 this number had increased to $15.53 \%$ (41.57\% for civil cases; numbers from Tribunal de Justiça do Estado de São Paulo, 2003). In several states, their case load was superior to that of the traditional justice system. In July 2010, SCTs were responsible for $27.9 \%$ of trials and $19.8 \%$ of all first instance decisions in São Paulo's judicial system (Corregedoria Geral da Justiça, 2010).

Still, Special Civil Tribunals were not the first attempt made in Brazil to extend access to justice to a larger fraction of the population. During the 1980s, law 7.224/1984 instituted Small Claims Courts (Tribunais de Pequenas Causas), from now on SCCs, which, among other things, intended to decentralize justice, to promote extra-legal conciliation, to judge matters that were

\footnotetext{
${ }^{6}$ These correspond, for example, to financial contracts through which a supplier finances an entrepreneur, or, more generally, private debt contracts.
} 
usually not taken to the official justice system, to simplify procedures, and to reduce the burden on traditional courts (Carneiro, 2003).

But SCCs did not have the authority to execute their own decisions and their rulings were not legally binding. Therefore, few states actually implemented the physical and material structure of Small Claims Courts (Cunha, 2008). The ones that were instituted were reported to operate under precarious conditions and to be ineffective because "they lacked the competence to implement their legal decisions, whose execution still accrued to the traditional justice system" (Cunha, 2008, p.52, translated by the authors).

With the 1988 Constitution and the creation of Special Civil Tribunals, the competencies of these courts were extended to include the execution of actions of their own responsibility. Whenever state laws were passed regulating the functioning of SCTs, previously existing SCCs were immediately converted into SCTs. Given the limited role played by SCCs in the process of extension of access to justice in Brazil, we concentrate our analysis on the creation of SCTs. Still, in some of our empirical exercises, we account for the previous existence of an SCC in locations that subsequently received SCTs and try to assess whether SCCS also had any effect on entrepreneurship.

According to the Brazilian Census Bureau (Instituto Brasileiro de Geografia e Estatística, IBGE), 34\% of Brazilian municipalities had at least one SCT in 2001. In the state of São Paulo, which constitutes our sample, this number was $47 \%$ (IBGE, 2001). We explore the fact that roughly half the municipalities in the state did not receive an SCT before 2000 to apply a difference-in-differences strategy. The remaining empirical concerns are discussed in the next section.

\section{Data and Empirical Strategy}

\subsection{Data}

Data on SCCS and SCTs location were provided by the Tribunal of Justice of São Paulo. We create dummy variables indicating the presence of an SCT within a given municipality (the creation of SCTs occurred typically in 1998 in the state of São Paulo). We also use information on the headquarters of judiciary districts (comarcas), the lowest level districts in the Brazilian justice system (obtained from the 1994 Statistical Yearbook of the state of São Paulo). We create a dummy variable indicating municipalities that housed headquarters of judiciary 
districts. We choose to restrict our analysis to the state of São Paulo due to data availability and to the fact that, ultimately, Special Civil Tribunals are part of the state justice systems. ${ }^{7}$ The state of São Paulo is particularly relevant because it is the largest economy in Brazil, accounting in 2007 for $33 \%$ of the country's GDP and $21 \%$ of its population.

Except for data on average per capita household income and credit availability, ${ }^{8}$ drawn from IPEADATA and from the Central Bank of Brazil, all other variables were constructed from census micro-files (1970, 1980, 1991 and 2000). Since there was a significant change in the number of Brazilian municipalities in this period, we use Minimum Comparable Areas (Áreas Mínimas Comparáveis), from now on MCAs, as units of analysis. MCAs are territorial units within the census that can be traced through time, allowing comparability of the same location across different periods.

Variables were always constructed so as to be made compatible across different census years (there were some changes in specific questions in the census during the period). The Appendix B presents in detail the procedures used to create consistent variables over time. The variables include individual and household characteristics (age, gender, schooling, whether the individual is a migrant; presence of water, sanitation, electricity, ownership of a car, and number of rooms in the household). The schooling variable was created based on the methodology suggested by Rigotti (2004). For homogeneity, we restrict the sample to individuals with an occupation, between ages 25 and 50 .

In relation to dependent variables, we use three measures of entrepreneurship: employer status, self-employed status, and a compound variable that we call entrepreneur, indicating either employer or self-employed status. We choose this strategy because selfemployed can often be regarded as small entrepreneurs, especially in industries dealing with outsourcing of a variety of services. We provide a detailed account of the major activities in which both self-employed and entrepreneurs are involved in Appendix Table A1. The

\footnotetext{
${ }^{7}$ It is also worth noticing that while in several states SCTs have mainly dealt with complaints against the public sector, especially in what comes to telecommunication services, in São Paulo the share of these actions in the total was among the lowest in the country (Centro de Estudos Brasileiros e Pesquisas Judiciais, 2006). Therefore, SCTs in the state played a different role from that seen in other areas, where they have been identified as "instances for complaints against services provided by the public sector" (Marques, 2006, translated by the authors).

${ }^{8}$ Data for total credit by municipality report the location where a loan is taken, which does not necessarily mean that the money is used within that location or the borrower is a local resident. This is the only credit variable we have at the municipality level, so we have no alternative to using it. This variable is only used in some robustness exercises.
} 
distribution of individuals by sector of activity is quite similar among employers and selfemployed, supporting the idea that these are actually not very different. In any case, in our empirical analysis, we conduct exercises for the three dependent variables separately.

\subsection{Empirical Strategy}

We explore the institutional change represented by the creation of Special Civil Tribunals (SCTs) to assess the impact of a reduction in the cost of access to justice on entrepreneurship (measured by the probability of occupation as employer or self-employed). We have data at the individual level before and after the institutional change - though we are not able to follow the same individuals - so we can control for unobserved attributes of MCAs that are fixed through time. We use a difference-in-differences strategy and compare the probability that individuals are entrepreneurs between municipalities that received an SCT and those that did not, before and after SCT implementation. Our baseline specification is:

$$
Y_{i, m, t}=\alpha+\left(\delta \times S C T_{m, t}\right)+\gamma^{\prime} X_{i, m, t}+B_{m}+\vartheta_{t}+\varepsilon_{i, m, t}
$$

where: $i, m$, and $t$ stand for individual $i$, in MCA $m$, and year $t ; Y_{i, m, t}$ is either entrepreneurial, employer or self-employed status (a binary variable); $X_{i, m, t}$ is a matrix of covariates; $S C T_{m, t}$ is a dummy variable that equals 1 whenever there was an operating Special Civil Tribunal at MCA $m$ in year $t ; B_{m}$ e $\vartheta_{t}$ are MCA and year fixed effects; $\varepsilon_{i, m, t}$ is a random term; and $\alpha, \delta$ and $\gamma$ are parameters.

In some specification, we also allow for heterogeneous effects, according to individual or MCA characteristics, or to distance to the closest SCT. In the basic specification, matrix $X_{i, m, t}$ includes a large set of individual controls: (i) gender, age and its square; (ii) indicators of household wealth such as treated water, sewage outflow connected to the public system, availability of electricity, car ownership and number of rooms, which are likely to condition the decision to become an entrepreneur through wealth constraints; and (iii) schooling and migrant status, to control for potential ability heterogeneity and labor market opportunities. Following, we control for MCA characteristics, which may affect individuals' occupational choice and be correlated with the presence of SCTs: \% of households with access to the general network of water supply and sewage outflow, \% of urban households, and income per capita, to account for local provision of public goods and economic development.

We cluster standard-errors at the MCA-level in order to allow for general autocorrelation of individual outcomes across individuals within an MCA, and within an MCA over 
time (following Bertrand et al, 2004). Under the usual assumption that the time-varying random term $\left(\varepsilon_{i, m, t}\right)$ is not correlated with covariates, the coefficient of interest $(\delta)$ gives the causal effect of SCTs on entrepreneurship. For simplicity, and due to an extremely large number of observations, we stick to the linear probability model throughout the paper.

There are two main potential problems in the use of a difference-in-differences strategy in this setting: omitted variables and endogeneity. First, it may be the case that municipalities that received SCTs also provided better public goods more generally, and we may end up attributing to SCTs the effects of these other dimensions of public goods. To deal with this problem, we include in some specifications the measures of provision of public goods discussed above (access to water, sanitation, and urbanization).

Second, implementation of SCTs may depend on municipalities' characteristics, and therefore the treatment variable may be endogenous. The use of municipality fixed-effects partly helps to deal with this problem, given that systematic time-invariant differences across municipalities are controlled for. But it does not solve it entirely, since the possibility of endogeneity persists in its dynamic version: program adoption may be associated with a particular evolution of the dependent variable, such as when more dynamic municipalities are more likely to receive SCTs.

We adopt three strategies to deal with this problem. First, we analyze explicitly in section 3.4 the determinants of SCT implementation. In addition, in the results section, we evaluate whether there are pre-existing trends on the dependent variables even before SCTs implementation. Finally, based on the results from section 3.4, we apply an instrumental variable strategy to deal with any remaining concern related to endogeneity of adoption. As will be clear later on, there is one judicial characteristic of MCAs that is virtually invariant over very long periods of time and that, after the approval of the Special Civil Tribunals law, was one of the main driving forces behind adoption: housing the headquarter of a judiciary district. So we build an instrument based on the interaction between the timing of approval of the law and the location of judiciary districts headquarters.

\subsection{Descriptive Statistics}

In Table 1 we present some descriptive statistics. For all census years in the sample (1970, 1980, 1991, and 2000), we present MCA averages of share of entrepreneurs (and employers and self-employed separately), average schooling, urbanization, and income per 
capita. These statistics are presented separately for MCAs that received an SCT by year 2000 and those that did not. The table highlights the main challenges in our empirical exercise: MCAs that received SCTs by year 2000 seem to be different from those that did not receive them.

Since the beginning of the sample period, MCAs that received SCTs were wealthier, with higher fractions of the population living in urban areas, and with higher levels of education. The differences persist throughout the period. This pattern should not surprise, since SCTs were more likely to be implemented in regional centers, with better infrastructure and more presence of the state.

In terms of our variables of interest, the share of employers was very similar throughout the period in MCAs that did and did not receive SCTs. Maybe surprisingly, MCAs receiving SCTs tended to have a lower fraction of self-employed individuals in the beginning of the period, while at the same time having a similar fraction of employers. This seeming contradiction comes from the fact that, historically, self-employment has been a low-skill occupation in Brazil: in our sample, the incidence of self-employment among individuals with elementary school or lower educational level is $19.8 \%$, as compared to $17.7 \%$ among those with higher levels of schooling (below and above median schooling for the sample, around 4 years). So areas with lower income and poorer labor market prospects tended to have higher incidence of selfemployment. At the same time, self-employment has been increasing throughout the period among individuals with higher than median schooling, from $15 \%$ in 1970 to $22 \%$ in 2000 .

As the table shows, for MCAs that did not receive SCTs, the incidence of selfemployment was reduced from $27 \%$ in 1970 to $21 \%$ in 2000 . On the other hand, for MCAs that received SCTS between 1991 and 2000, the incidence of self-employment was reduced from $22 \%$ to $20 \%$ between 1970 and 1991, but then increased to $23 \%$ by year 2000 .

\subsection{Special Civil Tribunals Implementation}

The descriptive analysis suggests that SCTs may have increased the fraction of individuals self-employed, but still there are concerns related to the heterogeneity of MCAs in the treatment and control groups. Despite the heterogeneity, if the implementation of SCTs is a function only of time-invariant characteristics, the presence of fixed effects in our difference-indifference approach deals with the problem. Otherwise, if implementation is endogenous and correlated with the dynamic behavior of dependent variables, the problem should be more of a concern. In order to assess the extent of this issue, following the logic of Galiani et al (2005), we 
analyze explicitly SCTs implementation. We run an MCA level probit regression of the presence of SCTs in 2000 on a set of time changing and pre-determined time invariant characteristics.

Specifically, the probit specification has as dependent variable a dummy indicating the presence of SCTs in 2000, and as independent variables 1980 levels and 1991-1980 differences of a large set of independent variables. Our independent variables (MCA averages) include levels and differences of all individual level controls used later on, plus our entrepreneurship indicators: self-employment and employer status, age and schooling, indicators of urban, male and migrant status, ownership of water, sewage, electricity, and cars, and number of rooms in the household.

Additionally, we include a dummy variable indicating whether the MCA was the headquarter of the local judiciary district (comarca). Administrative and logistic considerations suggest that the implementation of SCTs would start in the judiciary district headquarters and then be expanded to the surrounding areas under its jurisdiction. Table 2 presents the results of our probit estimation (as marginal effects).

The table presents three columns: the first two exclude the judiciary district dummy and include different sets of variables, while the third one includes all independent variables plus the judiciary district dummy. The table shows that pre-determined (1980) characteristics were highly correlated with SCT implementation. In the first two columns, MCAs with higher fraction of employers, higher urbanization, higher schooling, and lower average population age were more likely to receive an SCT in the years between 1991 and 2000. Quantitatively, 30 percentage points more in the fraction of households living in urban areas in 1980, or 1 more year of average schooling, would be associated with a 30 percentage point increase in the probability of receiving an SCT between 1991 and 2000.

But column 3 shows that this correlation is due to the fact that municipalities with these characteristics were more likely to be headquarters of judiciary districts. Once we include the judiciary district dummy, the effect of most of these variables ceases to be significant. Being the headquarter of a judiciary district is by far the main driving force behind SCT expansion, increasing the probability of implementation by 68 percentage points. This result assures some degree of exogeneity in the expansion of SCTs, since judiciary district headquarters are highly persistent over time and bear no obvious relationship to short run changes taking place at a location at a point in time (for example, $98 \%$ of the judiciary district headquarters in 1994 were 
judiciary district headquarters already in 1969). So the impression conveyed by Table 1 - that wealthier and more urban municipalities were more likely to receive SCTs - is indeed confirmed, but this comes mostly from the fact that these municipalities were the headquarters of local judiciary districts.

More importantly, the change in the dependent variables (share of employers and selfemployed) between 1980 and 1991 seems to play virtually no role in the implementation of SCTs. The change in the number of employers appears as significant at the $10 \%$ level only in the third column, and even then with a small quantitative effect: a $50 \%$ increase in the fraction of employers from the 1980 average would be associated with a 5 percentage point increase in the probability of SCT implementation. Even if taken at face value, this number is very small in comparison to the role played by the judiciary district dummy.

Overall, time varying factors play very little role, if any, in determining later SCT implementation. In column 1, none of the coefficients on the nine variables indicating changes between 1980 and 1991 are statistically significant at the 5\% level, while in column 2 only two out of twelve coefficients are (with very small quantitative impacts as compared to those of the variables in 1980), and in column 3 only one coefficient is.

These results are reassuring in that they do not indicate that SCT implementation was substantially affected by past shocks to the dependent variables. In principle, it seems that the problem of dynamic endogeneity is not too serious and we can proceed with the strategy outlined before. Still, we readdress this concern throughout the next section.

\section{Results}

\subsection{Benchmark Specification}

Table 3 shows the results from our benchmark specification. We use as dependent variables our composite definition of entrepreneur, but also its components separately (employer and self-employed). ${ }^{9}$ As discussed before, we include as individual-level controls a dummy of male gender, age and age squared, a dummy indicating urban residence, indicators of household infrastructure and wealth (dummies for treated water, sewage, and electricity in the household, number of cars, and number of rooms in the house), years of schooling, and a

\footnotetext{
${ }^{9}$ When using self-employed as dependent variable, we exclude employers from the sample, since those can be regarded as 'higher intensity' entrepreneurs than self-employed ones.
} 
dummy indicating whether the individual is a migrant. All specifications contain year and MCA fixed effects.

In columns 1 to 3 , we consider a single dummy for SCT implementation, not allowing for heterogeneity of the effect across individuals. In columns 4 to 6 , we allow the effects to vary according to the level of schooling (different coefficients below and above 4 years of schooling, the median educational attainment in the sample). The results show a significant relationship between SCT implementation and entrepreneurship, be it measured by employer, selfemployed, or either of those. According to the point estimates from columns 1 to 3 , implementation of SCTs is associated with a 3.86 percentage point increase in the probability that an individual is an entrepreneur $(0.4$ percentage point for employers and 3.74 for selfemployed). ${ }^{10}$

Columns 4 to 6 show that the effect of SCTs on entrepreneurship comes mostly from individuals with higher levels of schooling. For our definition of entrepreneur, the effect of SCTs is 1.93 percentage points and significant at $5 \%$ for individuals below the median level of schooling, while it is 4.60 percentage points and significant at $1 \%$ for individuals above it. Our reading of this heterogeneity is that it is not necessarily linked to schooling per se, but rather to overall socioeconomic conditions. SCTs seem to have increased entrepreneurship particularly among individuals of higher socioeconomic background. Estimated coefficients are quantitatively large, corresponding to $14.8 \%$ of the 1991 average entrepreneurship and $27.4 \%$ of the 1991 average self-employment (for individuals above median schooling living in MCAs that received SCTs).

Some interesting patterns also arise in the control variables included in the table. Overall, entrepreneurship is higher among men and in urban areas, and it increases in a concave fashion with age, peaking at the age of 60 . Most of the wealth and infrastructure related variables display a positive and significant sign, ${ }^{11}$ but schooling displays a negative one. A possible rationalization for this result would be that household wealth relaxes liquidity constraints, increasing the probability of entrepreneurship; but, conditional on wealth, individuals with higher schooling have better labor market perspectives as employees and,

\footnotetext{
${ }^{10}$ The point-estimates for employer and self-employed do not add up to the effect on entrepreneurs because of the differences in the sample (see previous footnote).

${ }^{11}$ The only exception is access to electricity, which has an extremely high coverage in Brazil.
} 
therefore, lower probability of entrepreneurship. ${ }^{12}$ The table also shows that migrants are typically less likely to be entrepreneurs, maybe due to higher liquidity constraints (though we have no way of testing this hypothesis here).

\subsection{Robustness}

As discussed at length before, the main potential problem with our empirical strategy is that MCAs receiving an SCT may be different from other MCAs. One possibility is that these MCAs are going through improvements in several other areas related to public good provision, not only access to justice. We assess this possibility in Table 4, by including as additional controls in our benchmark specification aggregate MCA level variables indicating provision of other types of public goods and socioeconomic characteristics.

First, in columns 1 to 3, we include the fraction of households in the MCA connected to the public water system, the fraction of households with access to toilet connected to the public sewage system, and the fraction of households living in urban areas. Though the coefficients are reduced by the introduction of the controls, the same qualitative pattern remains: we find a significant and quantitatively important impact of SCTs on entrepreneurship. In columns 4 to 6 , we include MCA measures of income per capita (In) and number of occupied individuals (In of the sum of employees, employers and self-employed individuals) as additional controls. Though both income and market size in the long run may be endogenous to entrepreneurship, and therefore should not belong to the right hand side of this equation, we use it as an extreme test as to whether the effect of the SCTs can be attributed to other socioeconomic changes taking place simultaneously at the MCA level. The results from columns 4 to 6 are virtually identical to those from columns 1 to 3 . In columns 7 to 12 , we run the same specifications allowing coefficients to vary according to the level of schooling and the same patterns noticed before arise.

Table 5 addresses a different concern. SCTs' effects may extend beyond the geographical boundaries of an MCA, by allowing sufficiently close neighboring populations to also access its lower-cost litigation technology. With that in mind, we redefine our treatment variable in two alternative ways: (i) instead of an indicator of SCT presence, we define an intensity variable that equals 1 if the MCA has an SCT in 2000 and, otherwise, smoothly decays

\footnotetext{
${ }^{12}$ See Gathak and Jiang (2002) for a model of occupational choice between subsistence, salaried work and entrepreneurship.
} 
to zero as its distance to the closest MCA with an SCT increases; ${ }^{13}$ and (ii) we define an indicator of SCT neighborhood that equals 1 if the MCA lies within a $30 \mathrm{~km}$ radius from an SCT, and 0 otherwise. Columns 1 to 6 present the results for the smooth decay definition, which are slightly larger than our baseline results. In columns 7 to 12 , which consider the indicator of SCT neighborhood as independent variable, results are much larger in magnitude, with pointestimates more than twice as large as the baseline estimates, corresponding to increases of 9.4 percentage points for overall entrepreneurship and 10.6 percentage points for individuals above the median education. This result suggests that it was indeed the case that SCTs helped foster entrepreneurship over a wider radius. ${ }^{14}$

A final concern relates to the timing of implementation of SCTs and their estimated impact. First, there is the possibility of previously existing differential trends across locations that did and did not receive SCTs. We already addressed this issue partly with Table 2 , where we showed that implementation of the SCTs was mostly related to time invariant characteristics of MCAs, particularly to the presence of judiciary district headquarters. Still, we go one step further and explicitly analyze whether there is evidence of pre-existing trends in entrepreneurship in MCAs that received SCTs. In order to do so, we create a dummy variable equal to 1 in the period immediately before the implementation of the SCT. ${ }^{15}$ Since some of the MCAs that received SCTs had previously SCCS, we also include SCC dummy variables in this specification (in order not to confound pre-existing trends with SCCs). ${ }^{16}$ Last, we reassess our baseline results restricting attention to the 1991-2000 period, as SCTs were implemented in São Paulo during this interval.

\footnotetext{
${ }^{13}$ More precisely, the SCT variable is modified to equal 1 if the MCA has an SCT in 2000, and $1-\exp (-1 /$ distance to closest SCT) otherwise, where distance is measured in $\mathrm{km}$.

${ }^{14}$ We cannot discard the alternative interpretation of general equilibrium effects, that is, of entrepreneurship having increased in MCAs surrounding those where SCTs were implemented because of indirect adjustment mechanisms linked to the initial increase in entrepreneurship among MCAs with an SCT. Notwithstanding, we can interpret it as the net effect of SCTs on entrepreneurship.

${ }^{15}$ In MCAs where an SCC was previously implemented, the placebo variable is equal to one in the period immediately before the implementation of the SCC, and 0 otherwise.

${ }^{16}$ As discussed in the institutional background section, in a very small number of municipalities that were to receive a SCT between 1991 and 2000, there was already another variety of local small claims court existing in 1991 (this happens in only $2 \%$ of the AMCs in the sample). These were pilot projects with very limited actual judicial power, so the legal literature regards their experience as having been ineffective. Still, to make sure that part of the effect that we are capturing with our benchmark specification is not coming from the previous existence of SCCs in some MCAs, we include the previous presence of a SCC as an additional control.
} 
For simplicity and ease of interpretation, we look only at the average effect in these exercises and do not run the specification with heterogeneous effects by educational level. The results are presented in Table 6. Panel A includes only the SCT and SCC indicators, Panel B includes additionally the placebo experiment, and Panel C considers the subsample restricted to 1991 and 2000. Qualitative results related to the SCT coefficient are similar to those obtained before across all specifications, even though a bit smaller in magnitude in Panel C. Moreover, we find no evidence of pre-existing trends for our definition of entrepreneurship and for selfemployed, but do find some evidence for the case of employers. It seems to be the case that MCAs that received SCTs already registered some increase in the number of employers even before SCT implementation. Notice that employers are responsible for only a very modest fraction of our estimated effect of access to justice on entrepreneurship. Roughly $95 \%$ of the quantitative effect comes from the response of self-employment, for which we have no evidence of pre-existing trends before SCT implementation. Still, in the next subsection, we propose a final strategy to deal with any remaining concerns in this direction.

\subsection{Instrumental Variable}

Given the evidence of some pre-existing trend in the case of employers, there may be remaining concerns that our results are driven by the endogenous dimension of variation in SCTs. As a final strategy to address this issue, we use an instrumental variable strategy to isolate the exogenous dimension of variation in SCTs implementation. The discussion from section 3.4 suggests that the presence of judiciary district headquarters in an MCA is the main driving force behind SCT adoption. Since the law regulating SCTs was approved only in 1998 in São Paulo, a natural instrument arises from the interaction of these two dimensions: a dummy variable that equals zero for all years before 1998 and, after that, equals one only for the MCAs that were headquarters of judiciary districts. Notice that headquarters of judiciary districts change very rarely over time, so it is difficult to associate them with variations taking place at a specific point in time. For example, among the judiciary district headquarters in 1994 (224), 98\% (219) were already judiciary district headquarters in $1969 .{ }^{17}$ So the proposed instrument relies on the interaction of a characteristic that is virtually time invariant (judiciary districts) with the timing of approval of the law that led to the implementation of Special Civil Tribunals.

\footnotetext{
${ }^{17}$ In addition, there were only 11 judiciary district headquarters in 1969 that had lost their positions by 1994 . See State Decree (Decreto-Lei) n.158, promulgated on October 281969 by the São Paulo State Congress.
} 
Table 2 suggests that this would be a valid strategy to isolate the exogenous component of variation in SCT implementation.

The results of this exercise are presented in Table 7. Since we have only one instrument, we focus on the specifications ignoring heterogeneity across educational levels. Panel A shows the first-stage results, while Panel B shows the second stage. In both cases, we present results analogous to those from columns 1 to 3 of Tables 3 and 4 (baseline results and results with aggregate controls for public goods provision). The first-stage results confirm that our instrument is strongly related to the implementation of SCTs: headquarters of judiciary districts in 1994 were more than 50 percentage points more likely to receive an SCT after 1991 . This result is almost identical if we use judiciary district headquarters from 1969 instead of 1994. The F statistic of the instrument shows no evidence of a weak instruments problem.

Second stage results are slightly weaker for the simplest specification, but roughly $50 \%$ larger for the specification with MCA level controls. In fact, in Panel B from Table 7, the introduction of aggregate controls has virtually no impact on estimated coefficients, indicating that our instrument seems to be doing the job. If anything, the instrumental variables evidence suggests that the endogenous dimension of variation in SCTs reduce their estimated impact on entrepreneurship. This might be expected if local changes correlated with SCT adoption improved labor market opportunities, reducing therefore the relative attractiveness of small entrepreneurship.

\subsection{Mechanisms}

We documented a relationship between the introduction of the low-cost litigation technology represented by SCTs and entrepreneurship. Still, there are many potential mechanisms behind this link.

The literature on the economic effects of contract enforcement considers several channels through which courts' operation can affect firms' expected profits and access to external financing, the two dimensions that interact to determine the equilibrium-level of entrepreneurship. These can be summarized by the following: (i) access to formal credit; (ii) access to trade credit or other informal financial arrangements; (iii) decreased probability of expropriation, be it of physical assets or intellectual property; and (iv) general equilibrium effects. 
On access to formal credit, a number of empirical papers document that better functioning judiciary systems are positively correlated with volume of credit, entrepreneurship, and firm size (see, for example, Rajan and Zingales, 1998). Furthermore, Lilienfeld-Toal et al (2009) find that the introduction of tribunals that enforce debt repayment increases credit availability. However, SCTs are not entitled to enforce debt contracts with banks, which rules out a direct effect of their introduction on formal access to credit. ${ }^{18}$ Nonetheless, because they can be used to enforce contracts among different parties along the production chain, firms' future cash flows could be more credibly offered as collateral to suppliers after SCTs were in place, therefore increasing access to trade credit and informal financing. Indirectly, this might also end up increasing the availability of financing through banks. Similarly, one might expect to see an increase in the incidence of more general state-contingent contracts (as discussed in Anderlini et al, 2007).

Additionally, the probability of expropriation falls with better enforcement of contracts. Because there is lower risk that those renting or using capital, or even employees, steal resources, either physical or intellectual, returns to entrepreneurship are higher and rental markets in physical capital are more developed (see Kumar et al, 2001). Kumar et al (2001) find this type of effect in non-capital-intensive industries in a sample of European countries, arguing that physical capital is already guaranteed in Europe by a minimum rule of law. In contrast, Laeven and Woodruff (2007) show that, in Mexico, capital-intensive industries are the ones that benefit the most from better judicial protection, supposedly because lack of property rights is more pervasive in the developing world.

Finally, general equilibrium effects in this context are unpredictable. If the increase in access to credit allows new suppliers to enter the market, then one would expect reduced price of inputs and positive effects on entrepreneurs' expected profits. Analogously, if new consumers or downstream firms entered the market, larger market size might also lead to higher profits (see the discussion in Laeven and Woodruff, 2007). But it could also be the case that increased access to credit would allow new competitors to finance their way into the market, or existing competitors to expand their operations, adversely affecting expected profits.

\footnotetext{
${ }^{18}$ According to the Law 9.099/1995, Art. 8ㅇ, § 1으, only microenterprises and small scale firms can start a litigation process in an SCT.
} 
Our data does not allow us to directly assess which mechanisms are behind the relationship between SCTs and higher entrepreneurship. Since we use household data, we have no information on entrepreneurs' access to financial services or informal credit arrangements. Moreover, we do not have data on individual experiences with litigation.

What we do instead is to conduct an exploratory exercise by analyzing the potential heterogeneity in responses across areas with different initial conditions and across sectors with different uses of capital. To assess the credit channel (which we cannot distinguish between formal or informal), we analyze whether entrepreneurship increased more or less depending on the level of credit availability before the institutional reform. To assess the expropriation probability channel, we look at whether entrepreneurship increased more in capital-intensive activities.

We explore these hypotheses in Table 8 . We first consider an interaction of our SCT variable with the initial availability of finance, measured in Panel A by the per capita credit (In) in 1997, a year before SCTs implementation in São Paulo. In Panel B, we interact the SCT dummy with the share of entrepreneurs in capital-intensive activities in 1991. We adopt the simplest possible definition for capital-intensive activities, comprising transformation industry, retail, transport and communication, and excluding activities linked to agriculture, mineral extraction, construction, personal services, services to firms, social activities and education. ${ }^{19}$ Following, in Panel C, we interact the SCT dummy with an indicator of whether the individual is an entrepreneur in capital-intensive activities. In order to try to account for general equilibrium effects, when relevant we control for market size and number of individuals employed in the sector.

The results in Panels A and B of Table 8 document that entrepreneurship - particularly self-employment - increased more where the initial levels of per capita credit supply and of entrepreneurship in capital intensive industries were higher. That point is clearly captured in Figures 1(a) and 1(b), which depict the net effect of SCTs on entrepreneurship by decile of the

\footnotetext{
${ }^{19}$ Table C.I in the Appendix details our choice of sectors, describing how we make industries compatible across censuses. We base our classification on aggregate figures from IBGE concerning the ratio of intermediate consumption related to raw materials and inputs to the gross value of production (gross revenues, for services). There is no readily available measure of the relative importance of physical capital by industry for Brazil. Some sectors that might be seen as capital intensive in certain developed countries - such as construction and agriculture - are typically not so in Brazil, where labor is extremely cheap (though there is a large capital intensive agricultural sector, when seen from the perspective of employment rather than production, agriculture is dominantly labor intensive).
} 
two variables indicating initial conditions. It turns out that the net effect of SCTs is positive and significant for all deciles of initial levels of credit, but ranges from about 1 percentage point in the bottom decile to almost 6 percentage points in the top decile. Along the same lines, the effect of SCTs is not statistically significant for the lowest decile of the 1991 share of entrepreneurship in capital-intensive activities, but is close to 6 percentage points in the top decile. Our reading of this pattern is that SCTs may have facilitated prospective entrepreneurs' relationship with finance providers where there was already a higher credit supply, and that this was particularly relevant where capital intensive activities were important. This would suggest that, at least until 2000, the supply of credit did not respond to increased contract enforcement. Rather, entrepreneurs seem to have become better able to access credit where supply already existed. This effect was particularly strong for areas with initially higher incidence of capital intensive activities, suggesting that these sectors were not realizing all potential profits before the implementation of SCTs.

This hypothesis is further supported by the results from Panel $C$. The results indicate that the response of entrepreneurship to SCT implementation was indeed stronger in capitalintensive activities. In other words, entrepreneurship increased more in areas that had initially higher levels of credit and incidence of capital intensive activities, and increased more precisely among these capital intensive activities. Overall, these patterns are consistent with the idea that SCTs reduced the risk of expropriation of physical assets, similarly to the findings of Laeven and Woodruff (2007).

Our interpretation is that SCTs implementation affected entrepreneurship mainly through property rights enforcement. The result that entrepreneurship increased more in capital-intensive activities - the ones that were likely to benefit from the new litigation technology - backs up the idea that lower probability of expropriation increases expected returns in activities for which physical assets are critical resources. This evidence also reinforces the causal interpretation of the previous results.

\section{Concluding Remarks}

This paper analyzes the impact of easier access to the justice system on entrepreneurship. We explore the creation of Special Civil Tribunals in the Brazilian state of São Paulo during the 1990s. Special Civil Tribunals increased the geographic presence of the justice 
system, simplified judicial procedures, and increased the speed of adjudication of disputes (mainly through facilitation of agreements in early stages of the process). We find that implementation of Special Civil Tribunals was correlated with increased entrepreneurship, defined as the probability that individuals are employers or self-employed. The evidence suggests that the increase in entrepreneurship was mainly driven by reduced risk of expropriation of physical assets. These results are particularly robust for the case of selfemployment, and do not seem to be related to other changes in infrastructure or public goods provision at the local level, nor to pre-existing trends in self-employment.

Historically, self-employment in Brazil has been particularly common among low-skill workers. This pattern seems to have been changing in the recent past. The evidence analyzed here suggests that access to justice increased the return to high skill self-employment, therefore being a potentially important determinant of its increased incidence. 


\section{References}

ACEMOGLU, D., S. JOHNSON, and J. ROBINSON (2005a): "Institutions as the fundamental cause of long-run economic growth", in Handbook of Economic Growth, ed by P. Aghion and S. Durlauf. North Holland.

ACEMOGLU, D. and S. JOHNSON (2005b): "Unbundling institutions," Journal of Political Economy, 113, 949-995.

AGHION, P., and P. BOLTON (1997): "A theory of trickle-down growth and development," The Review of Economics Studies, 2, 151-172.

ANDERLINI, L., L. FELLI and A. POSTLEWAITE (2007): "Courts of law and unforeseen contingencies," Journal of Law, Economics and Organization, 23, 662-684.

ANTUNES, A., T. CAVALCANTI, and A. VILLAMIL (2008): "The effect of financial repression and enforcement on entrepreneurship and economic development," Journal of Monetary Economics, 55, 278-297.

ARRIGONI, C., B. FUNCHAL, and J. DE MELLO (2010): "The Brazilian Payroll Lending experiment," PUC-Rio Discussion Paper No. 573, April, 2010.

BANERJEE, A., and A. NEWMAN (1993): "Occupational choice and the process of development," Journal of Political Economy, 101, 274-298.

BERTRAND, M., E. DUFLO and S. MULLAINATHAN (2004): "How Much Should We Trust Differences-in-Differences Estimates?" Quarterly Journal of Economics, 119(1), 249-275.

CASAS-ARCE, P. and A. SAIZ (2010): "Owning versus renting: do courts matter?" Journal of Law and Economics, 53, 137-164.

CARNEIRO, P.C.P. (2006): Acesso à justiça: Juizados Especiais Cíveis e ação civil pública. Editora Forense.

CASTELAR PINHEIRO, A. (2000): Judiciário e Economia no Brasil. São Paulo, Sumaré.

CENTRO DE ESTUDOS BRASILEIROS E PESQUISAS JUDICIAIS (2006): "Juizados Especiais Cíveis um estudo."

CHEMIN, M. (2009a): "The impact of judiciary on entrepreneurship: evaluation of Pakistan's Access to Justice Program," Journal of Public Economics, 93, 114-125.

CHEMIN, M. (2009b): "Do judiciaries matter for development? Evidence from India," Journal of Comparative Economics, 37, 230-250.

CORREGEDORIA GERAL DA JUSTIÇA (2010): “Comunicado CG No. 1804/2010."

CORSEUIL, C. and M. FOGUEL (2002): "Uma sugestão de deflatores para rendas obtidas a partir de algumas pesquisas domiciliares do IBGE," IPEA Discussion paper No. 897.

COSTA, A., and J. DE MELLO (2008): "Judicial risk and credit market performance: micro evidence from Brazilian payroll loans," NBER Working Paper No. 12252, May, 2006.

CUNHA, L.G. (2008): Juizado Especial Cível - Criação, instalação, funcionamento e a democratização do acesso à justiça. Editora Saraiva. 
GALIANI, S., P.J. GERTLER, and E. SCHARGRODSKY (2005): "Water for Life: The Impact of the Privatization of Water Services on Child Mortality," Journal of Political Economy, 113(1), 83120.

GATHAK, M., and N. JIANG (2002): "A simple model of inequality, occupational choice, and development", Journal of Development Economics, 69, 205-226.

IBGE (2001): "Equipamentos municipais de justiça e segurança pública," in Base de Informações Municipais 2001. Instituto Brasileiro de Geografia e Estatística.

JAPELLI, T., M. PAGANO, and M. BIANCO (2005): "Courts and banks: effects of judicial enforcement on credit markets," Journal of Money, Credit and Banking, 37, 223-244.

KUMAR, R. RAJAN and L. ZINGALES (2001): “What determines firm size?,” Unpublished working paper, University of Chicago.

LAVEN, L. and C. WOODRUFF (2007): "The quality of the legal system, firm ownership, and firm size," Review of Economics and Statistics, 89, 601-614.

LILIENFELD-TOAL, U., D. MOOKHERJEE, and S. VISARIA (2009): "The Distributive Impact of Reforms in Credit Enforcement: Evidence from Indian Debt Recovery Tribunals," IPC Working Paper Series Number 85.

MADEIRA, G., M. RANGEL, and M. RODRIGUES (2010) "Judicial risk and borrowing constraints: inferential evidence from changes in the availability of credit instruments," unpublished manuscript.

MARQUES, E. (2006): “Acesso à justiça: estudo de três Juizados Especiais Cíveis no Estado de São Paulo," USP Department of Political Sciences, Phd Thesis.

NARITOMI, J., R.R. SOARES, and J.J. ASSUNÇÃO (2009): "Institutional Development and Colonial Heritage within Brazil," IZA Discussion Paper 4276.

QUINTIN, E. (2008): "Contract enforcement and the size of the informal economy," Economic Theory, 37, 395-416.

RIGOTTI, J. (2004): "Variáveis de educação dos censos demográficos brasileiros de 1960 a 2000," in Introdução à demografia da educação, ed by Eduardo Luiz G. Rios-Neto and Juliana de Lucena Ruas Riani. Associação Brasileira de Estudos Populacionais - ABEP.

TOURINHO NETO, F. and J. FIGUEIRA JÚNIOR (2007): Juizados Especiais Estaduais Cíveis e Criminais - Comentário à lei 9.099/1995. Editora Revista dos Tribunais.

TRIBUNAL DE JUSTIÇA DO ESTADO DE SÃO PAULO (2003): “Relatório de Gestão Anual de 2003."

VISARIA, S. (2009): "Legal reform and loan repayment: the microeconomic impact of debt recovery tribunals in India," American Economic Journal: Applied Economics, 3, 59-81. 
Table 1: Descriptive Statistics - MCAs in the state of São Paulo, Brazil - 1970-2000

\begin{tabular}{|c|c|c|c|c|c|c|c|c|}
\hline & \multicolumn{2}{|c|}{1970} & \multicolumn{2}{|c|}{1980} & \multicolumn{2}{|c|}{1991} & \multicolumn{2}{|c|}{2000} \\
\hline & No SCT & $\begin{array}{l}\text { SCT in } \\
2000\end{array}$ & No SCT & $\begin{array}{l}\text { SCT in } \\
2000\end{array}$ & No SCT & $\begin{array}{l}\text { SCT in } \\
2000\end{array}$ & No SCT & $\begin{array}{c}\text { SCT in } \\
2000\end{array}$ \\
\hline Entrepreneur & 0.29 & 0.25 & 0.28 & 0.25 & 0.24 & 0.26 & 0.24 & 0.27 \\
\hline Employer & 0.02 & 0.02 & 0.04 & 0.04 & 0.05 & 0.06 & 0.03 & 0.04 \\
\hline Self Employed & 0.27 & 0.22 & 0.24 & 0.21 & 0.19 & 0.20 & 0.21 & 0.23 \\
\hline Schooling & 2.11 & 3.13 & 3.21 & 4.22 & 5.01 & 6.01 & 6.25 & 7.23 \\
\hline Urban & 0.37 & 0.66 & 0.51 & 0.78 & 0.68 & 0.84 & 0.77 & 0.89 \\
\hline $\begin{array}{l}\text { Per Capita } \\
\text { Income }\end{array}$ & 58.74 & 89.08 & 164.42 & 221.89 & 146.29 & 197.18 & 237.87 & 324.57 \\
\hline
\end{tabular}

Obs.: 257 MCAs out of 567 had received a SCT by year 2000. Census data. Per capita income in $2000 \mathrm{R} \$$. 
Table 2: Adoption of SCT - Probit Results - MCAs in the state of São Paulo, Brazil

\begin{tabular}{|c|c|c|c|}
\hline Vars & (1) & (2) & (3) \\
\hline \multicolumn{4}{|l|}{ Change btwn 1980 and 1990: } \\
\hline \multirow[t]{2}{*}{$\Delta$ self-employed } & 0.787 & 0.402 & 1.278 \\
\hline & [0.579] & [0.634] & [0.902] \\
\hline \multirow[t]{2}{*}{$\Delta$ employer } & 1.944 & 2.101 & $2.697^{*}$ \\
\hline & [1.332] & [1.359] & [1.603] \\
\hline \multirow[t]{2}{*}{$\Delta$ urban } & -0.622 & -0.451 & 0.225 \\
\hline & [0.483] & [0.479] & [0.582] \\
\hline \multirow[t]{2}{*}{$\Delta$ age } & $-0.115^{*}$ & -0.0992 & $-0.160^{* *}$ \\
\hline & {$[0.0634]$} & [0.0617] & [0.0815] \\
\hline \multirow[t]{2}{*}{$\Delta$ schooling } & 0.0342 & 0.0261 & -0.0178 \\
\hline & [0.0697] & {$[0.0850]$} & [0.101] \\
\hline \multirow[t]{2}{*}{$\Delta$ male } & -0.866 & -1.091 & -0.605 \\
\hline & [0.925] & [0.931] & [1.104] \\
\hline \multirow[t]{2}{*}{$\Delta$ water } & 0.341 & 0.349 & -0.141 \\
\hline & [0.512] & {$[0.516]$} & [0.620] \\
\hline \multirow[t]{2}{*}{$\Delta$ sewage } & -0.276 & -0.293 & -0.354 \\
\hline & {$[0.194]$} & [0.208] & [0.260] \\
\hline \multirow[t]{2}{*}{$\Delta$ electrivity } & -0.0336 & 0.661 & 1.249 \\
\hline & [0.721] & [0.782] & [1.141] \\
\hline \multirow[t]{2}{*}{$\Delta$ migrant } & & $-0.796^{\star *}$ & 0.113 \\
\hline & & {$[0.363]$} & [0.447] \\
\hline \multirow[t]{2}{*}{$\Delta$ rooms } & & $0.229^{*}$ & 0.179 \\
\hline & & {$[0.120]$} & [0.153] \\
\hline \multirow[t]{2}{*}{$\Delta$ car } & & $-1.704^{* * *}$ & $-1.176^{*}$ \\
\hline & & [0.637] & {$[0.696]$} \\
\hline \multicolumn{4}{|l|}{ Levels in 1980: } \\
\hline \multirow[t]{2}{*}{ judiciary district headquarter } & & & $0.683^{* * *}$ \\
\hline & & & [0.0483] \\
\hline \multirow[t]{2}{*}{ self-employed } & 0.817 & 0.790 & $1.402^{*}$ \\
\hline & [0.502] & {$[0.557]$} & [0.815] \\
\hline \multirow{2}{*}{ employer } & $3.085^{\star \star}$ & $3.536^{\star \star}$ & $3.642^{\star \star}$ \\
\hline & {$[1.319]$} & {$[1.400]$} & {$[1.826]$} \\
\hline \multirow[t]{2}{*}{ urban } & $1.017^{\star \star}$ & $0.875^{\star}$ & 0.92 \\
\hline & {$[0.461]$} & [0.479] & [0.577] \\
\hline \multirow[t]{2}{*}{ age } & $-0.166^{*}$ & -0.0662 & -0.0842 \\
\hline & [0.0914] & [0.0929] & [0.104] \\
\hline \multirow[t]{2}{*}{ schooling } & $0.335^{\star \star \star}$ & $0.350^{\star * \star}$ & 0.142 \\
\hline & [0.0612] & [0.0722] & [0.0866] \\
\hline \multirow[t]{2}{*}{ male } & -1.205 & -1.357 & -0.29 \\
\hline & [0.899] & [0.912] & [1.057] \\
\hline water & 0.216 & 0.339 & 0.18 \\
\hline & {$[0.479]$} & [0.494] & [0.569] \\
\hline sewage & 0.161 & 0.156 & 0.0857 \\
\hline & {$[0.176]$} & {$[0.211]$} & [0.244] \\
\hline electrivity & $-1.277^{* *}$ & -0.111 & 0.781 \\
\hline & {$[0.639]$} & {$[0.726]$} & [0.965] \\
\hline migrant & & $-0.645^{\star * *}$ & -0.134 \\
\hline & & {$[0.248]$} & {$[0.310]$} \\
\hline rooms & & $-0.198^{* *}$ & $-0.230^{\star *}$ \\
\hline & & [0.0951] & {$[0.115]$} \\
\hline car & & 0.399 & 0.172 \\
\hline & & {$[0.609]$} & [0.671] \\
\hline
\end{tabular}

Observations

567

567

567

Obs.: Marg effects. Robust std errors in brackets; ${ }^{* \star}{ }^{\star *} p<0.01,{ }^{\star \star} \mathrm{p}<0.05,{ }^{*} \mathrm{p}<0.1$. Dep var is dummy indicating presence of SCT in 2000. Indep vars in levels in 1980 and in diffs btwn 1990-1980 are MCA aggregates (for individuals btwn 25 and 55): \% selfemployed, \% employer, \% urban, avg age, avg schooling, \% male, \% of hh with water, sewage, and electricity, \% migrant, avg number rooms per hh, \% hh with car. Dummy for MCAs that are headquarters of judiciary districts also included. Census data. 
Table 3: Effect of SCT on Entrepreneurship - OLS Results, Benchmark Specifications -

MCAs in the state of São Paulo, Brazil - 1970-2000

\begin{tabular}{|c|c|c|c|c|c|c|}
\hline Vars & $\begin{array}{c}\text { (1) } \\
\text { entrepreneur }\end{array}$ & $\begin{array}{c}(2) \\
\text { employer }\end{array}$ & $\begin{array}{c}(3) \\
\text { self-employed }\end{array}$ & $\begin{array}{c}(4) \\
\text { entrepreneur }\end{array}$ & $\begin{array}{c}\text { (5) } \\
\text { employer }\end{array}$ & $\begin{array}{c}(6) \\
\text { self-employed }\end{array}$ \\
\hline SCT & $\begin{array}{l}0.0386^{* * *} \\
{[0.00851]}\end{array}$ & $\begin{array}{l}0.00393^{* * *} \\
{[0.00152]}\end{array}$ & $\begin{array}{l}0.0374^{\star * *} \\
{[0.00852]}\end{array}$ & & & \\
\hline $\begin{array}{l}\text { SCT below median } \\
\text { schooling }\end{array}$ & & & & $\begin{array}{l}0.0193^{\star *} \\
{[0.00920]}\end{array}$ & $\begin{array}{l}0.000610 \\
{[0.00160]}\end{array}$ & $\begin{array}{l}0.0187^{\star \star} \\
{[0.00870]}\end{array}$ \\
\hline $\begin{array}{l}\text { SCT above median } \\
\text { schooling }\end{array}$ & & & & $\begin{array}{l}0.0460^{* * *} \\
{[0.00806]}\end{array}$ & $\begin{array}{l}0.00522^{* * *} \\
{[0.00175]}\end{array}$ & $\begin{array}{l}0.0450^{\star \star *} \\
{[0.00817]}\end{array}$ \\
\hline male & $\begin{array}{c}0.105^{\star \star \star} \\
{[0.00372]}\end{array}$ & $\begin{array}{l}0.0345^{\star \star \star} \\
{[0.00137]}\end{array}$ & $\begin{array}{l}0.0823^{\star * \star} \\
{[0.00429]}\end{array}$ & $\begin{array}{c}0.105^{\star * \star} \\
{[0.00367]}\end{array}$ & $\begin{array}{l}0.0345^{* * *} \\
{[0.00138]}\end{array}$ & $\begin{array}{l}0.0823^{* * *} \\
{[0.00423]}\end{array}$ \\
\hline age & $\begin{array}{c}0.0176^{\star \star \star} \\
{[0.000676]}\end{array}$ & $\begin{array}{l}0.00435^{\star * *} \\
{[0.000177]}\end{array}$ & $\begin{array}{c}0.0139^{* * *} \\
{[0.000578]}\end{array}$ & $\begin{array}{c}0.0175^{\star \star \star} \\
{[0.000683]}\end{array}$ & $\begin{array}{l}0.00434^{\star * *} \\
{[0.000177]}\end{array}$ & $\begin{array}{c}0.0138^{\star \star \star} \\
{[0.000581]}\end{array}$ \\
\hline age^2 & $\begin{array}{c}-0.000147^{* * *} \\
{[6.25 \mathrm{e}-06]}\end{array}$ & $\begin{array}{c}-3.86 e-05^{* * *} \\
{[2.77 e-06]}\end{array}$ & $\begin{array}{c}-0.000109^{* * *} \\
{[5.73 \mathrm{e}-06]}\end{array}$ & $\begin{array}{c}-0.000145^{\star * *} \\
{[6.27 \mathrm{e}-06]}\end{array}$ & $\begin{array}{c}-3.83 e-05^{* * *} \\
{[2.72 e-06]}\end{array}$ & $\begin{array}{c}-0.000107^{* * *} \\
{[5.73 e-06]}\end{array}$ \\
\hline urban & $\begin{array}{l}0.0217^{* * *} \\
{[0.00514]}\end{array}$ & $\begin{array}{c}0.0105^{\star * \star} \\
{[0.000946]}\end{array}$ & $\begin{array}{l}0.0158^{\star * *} \\
{[0.00526]}\end{array}$ & $\begin{array}{l}0.0214^{\star * \star} \\
{[0.00524]}\end{array}$ & $\begin{array}{c}0.0104^{* * *} \\
{[0.000945]}\end{array}$ & $\begin{array}{l}0.0156^{\star * \star} \\
{[0.00537]}\end{array}$ \\
\hline water & $\begin{array}{l}0.00799^{\star *} \\
{[0.00376]}\end{array}$ & $\begin{array}{l}-0.00609^{* * *} \\
{[0.000904]}\end{array}$ & $\begin{array}{l}0.0125^{\star * *} \\
{[0.00329]}\end{array}$ & $\begin{array}{l}0.00840^{* *} \\
{[0.00392]}\end{array}$ & $\begin{array}{l}-0.00602^{* * *} \\
{[0.000914]}\end{array}$ & $\begin{array}{l}0.0129^{\star * *} \\
{[0.00346]}\end{array}$ \\
\hline sewage & $\begin{array}{l}0.00829^{*} \\
{[0.00443]}\end{array}$ & $\begin{array}{l}0.00369^{* * *} \\
{[0.000901]}\end{array}$ & $\begin{array}{c}0.00519 \\
{[0.00516]}\end{array}$ & $\begin{array}{c}0.00835^{\star} \\
{[0.00452]}\end{array}$ & $\begin{array}{l}0.00370^{\star * *} \\
{[0.000884]}\end{array}$ & $\begin{array}{c}0.00524 \\
{[0.00524]}\end{array}$ \\
\hline electricity & $\begin{array}{l}-0.0311^{* * *} \\
{[0.00720]}\end{array}$ & $\begin{array}{l}-0.00847^{* * *} \\
{[0.00140]}\end{array}$ & $\begin{array}{l}-0.0248^{* * *} \\
{[0.00810]}\end{array}$ & $\begin{array}{l}-0.0301^{* * *} \\
{[0.00708]}\end{array}$ & $\begin{array}{l}-0.00831^{* * *} \\
{[0.00145]}\end{array}$ & $\begin{array}{l}-0.0239^{* * *} \\
{[0.00802]}\end{array}$ \\
\hline car & $\begin{array}{l}0.0922^{* * *} \\
{[0.00712]}\end{array}$ & $\begin{array}{l}0.0385^{* * *} \\
{[0.00143]}\end{array}$ & $\begin{array}{l}0.0657^{* * *} \\
{[0.00684]}\end{array}$ & $\begin{array}{l}0.0923^{* * *} \\
{[0.00716]}\end{array}$ & $\begin{array}{l}0.0385^{\star * *} \\
{[0.00144]}\end{array}$ & $\begin{array}{l}0.0658^{\star * *} \\
{[0.00688]}\end{array}$ \\
\hline rooms & $\begin{array}{l}0.0136^{* * *} \\
{[0.00163]}\end{array}$ & $\begin{array}{c}0.0107^{* * *} \\
{[0.000214]}\end{array}$ & $\begin{array}{l}0.00631^{* * *} \\
{[0.00179]}\end{array}$ & $\begin{array}{l}0.0136^{\star \star *} \\
{[0.00164]}\end{array}$ & $\begin{array}{c}0.0107^{* * *} \\
{[0.000217]}\end{array}$ & $\begin{array}{c}0.00637^{* * *} \\
{[0.00180]}\end{array}$ \\
\hline schooling & $\begin{array}{l}-0.00176^{\star * *} \\
{[0.000148]}\end{array}$ & $\begin{array}{l}0.00266^{\star * *} \\
{[7.81 \mathrm{e}-05]}\end{array}$ & $\begin{array}{c}-0.00400^{* * *} \\
{[0.000144]}\end{array}$ & $\begin{array}{l}-0.00221^{* * *} \\
{[0.000171]}\end{array}$ & $\begin{array}{l}0.00258^{\star * *} \\
{[7.00 \mathrm{e}-05]}\end{array}$ & $\begin{array}{l}-0.00445^{\star * *} \\
{[0.000165]}\end{array}$ \\
\hline migrant & $\begin{array}{c}-0.0270^{* * *} \\
{[0.00440]}\end{array}$ & $\begin{array}{c}-0.00169^{* * *} \\
{[0.000607]}\end{array}$ & $\begin{array}{c}-0.0265^{\star \star \star} \\
{[0.00431]}\end{array}$ & $\begin{array}{c}-0.0266^{* \star *} \\
{[0.00447]}\end{array}$ & $\begin{array}{c}-0.00162^{* * *} \\
{[0.000605]}\end{array}$ & $\begin{array}{c}-0.0261^{\star \star \star} \\
{[0.00439]}\end{array}$ \\
\hline Observations & $4,095,694$ & $4,095,694$ & $3,924,953$ & $4,095,694$ & $4,095,694$ & $3,924,953$ \\
\hline R-squared & 0.068 & 0.063 & 0.048 & 0.068 & 0.063 & 0.048 \\
\hline
\end{tabular}


Table 4: Effect of SCT on Entrepreneurship - OLS Results, MCA Level Controls MCAs in the state of São Paulo, Brazil - 1970-2000

\begin{tabular}{|c|c|c|c|c|c|c|c|c|c|c|c|c|}
\hline Vars & $\begin{array}{l}\text { (1) } \\
\text { ent }\end{array}$ & $\begin{array}{c}(2) \\
\text { emp }\end{array}$ & $\begin{array}{l}(3) \\
\text { self }\end{array}$ & $\begin{array}{l}(4) \\
\text { ent }\end{array}$ & $\begin{array}{l}(5) \\
\text { emp }\end{array}$ & $\begin{array}{l}(6) \\
\text { self }\end{array}$ & $\begin{array}{l}(7) \\
\text { ent }\end{array}$ & $\begin{array}{c}(8) \\
\text { emp }\end{array}$ & $\begin{array}{l}(9) \\
\text { self }\end{array}$ & $\begin{array}{l}(10) \\
\text { ent }\end{array}$ & $\begin{array}{l}(11) \\
\text { emp }\end{array}$ & $\begin{array}{l}(12) \\
\text { self }\end{array}$ \\
\hline SCT & $\begin{array}{c}0.0125^{\star \star} \\
{[0.00564]}\end{array}$ & $\begin{array}{c}0.00293 \\
{[0.00185]}\end{array}$ & $\begin{array}{c}0.0112^{* *} \\
{[0.00523]}\end{array}$ & $\begin{array}{c}0.0123^{\star *} \\
{[0.00562]}\end{array}$ & $\begin{array}{c}0.00253 \\
{[0.00180]}\end{array}$ & $\begin{array}{c}0.0113^{\star *} \\
{[0.00523]}\end{array}$ & & & & & & \\
\hline $\begin{array}{l}\text { SCT below median } \\
\text { schooling }\end{array}$ & & & & & & & $\begin{array}{l}-0.00389 \\
{[0.00640]}\end{array}$ & $\begin{array}{l}-0.000210 \\
{[0.00234]}\end{array}$ & $\begin{array}{l}-0.00460 \\
{[0.00567]}\end{array}$ & $\begin{array}{l}-0.00408 \\
{[0.00637]}\end{array}$ & $\begin{array}{l}-0.000603 \\
{[0.00228]}\end{array}$ & $\begin{array}{l}-0.00459 \\
{[0.00568]}\end{array}$ \\
\hline $\begin{array}{l}\text { SCT above median } \\
\text { schooling }\end{array}$ & & & & & & & $\begin{array}{l}0.0199^{* * *} \\
{[0.00547]}\end{array}$ & $\begin{array}{l}0.00435^{\star *} \\
{[0.00178]}\end{array}$ & $\begin{array}{l}0.0187^{\star \star *} \\
{[0.00514]}\end{array}$ & $\begin{array}{l}0.0198^{* * *} \\
{[0.00546]}\end{array}$ & $\begin{array}{l}0.00395^{\star *} \\
{[0.00175]}\end{array}$ & $\begin{array}{l}0.0188^{\star * *} \\
{[0.00515]}\end{array}$ \\
\hline MCA aggregate vari & bles: & & & & & & & & & & & \\
\hline water & $\begin{array}{c}-0.0493^{* * *} \\
{[0.0140]}\end{array}$ & $\begin{array}{c}-0.00844^{* *} \\
{[0.00344]}\end{array}$ & $\begin{array}{c}-0.0441^{* * *} \\
{[0.0145]}\end{array}$ & $\begin{array}{c}-0.0487^{* * *} \\
{[0.0124]}\end{array}$ & $\begin{array}{l}-0.00664^{*} \\
{[0.00366]}\end{array}$ & $\begin{array}{c}-0.0444^{\star \star \star} \\
{[0.0135]}\end{array}$ & $\begin{array}{c}-0.0485^{\star * *} \\
{[0.0139]}\end{array}$ & $\begin{array}{c}-0.00828^{* *} \\
{[0.00346]}\end{array}$ & $\begin{array}{c}-0.0433^{* * *} \\
{[0.0145]}\end{array}$ & $\begin{array}{c}-0.0481^{* \star *} \\
{[0.0124]}\end{array}$ & $\begin{array}{l}-0.00652^{*} \\
{[0.00367]}\end{array}$ & $\begin{array}{c}-0.0438^{\star \star *} \\
{[0.0134]}\end{array}$ \\
\hline sewage & $\begin{array}{l}-0.0214^{*} \\
{[0.0125]}\end{array}$ & $\begin{array}{c}-0.0111^{* * *} \\
{[0.00399]}\end{array}$ & $\begin{array}{l}-0.0144 \\
{[0.0146]}\end{array}$ & $\begin{array}{c}-0.0250^{\star *} \\
{[0.0118]}\end{array}$ & $\begin{array}{c}-0.0127^{\star \star \star} \\
{[0.00456]}\end{array}$ & $\begin{array}{l}-0.0171 \\
{[0.0142]}\end{array}$ & $\begin{array}{l}-0.0207^{*} \\
{[0.0123]}\end{array}$ & $\begin{array}{c}-0.0109^{\star * *} \\
{[0.00403]}\end{array}$ & $\begin{array}{l}-0.0137 \\
{[0.0145]}\end{array}$ & $\begin{array}{c}-0.0243^{\star *} \\
{[0.0116]}\end{array}$ & $\begin{array}{c}-0.0126^{\star * *} \\
{[0.00461]}\end{array}$ & $\begin{array}{c}-0.0164 \\
{[0.0140]}\end{array}$ \\
\hline urban & $\begin{array}{l}-0.136^{* \star *} \\
{[0.0134]}\end{array}$ & $\begin{array}{c}0.00757 \\
{[0.00971]}\end{array}$ & $\begin{array}{c}-0.145^{* * *} \\
{[0.0141]}\end{array}$ & $\begin{array}{l}-0.149^{\star \star *} \\
{[0.0162]}\end{array}$ & $\begin{array}{c}6.91 \mathrm{e}-05 \\
{[0.00744]}\end{array}$ & $\begin{array}{c}-0.155^{\star \star \star} \\
{[0.0180]}\end{array}$ & $\begin{array}{l}-0.131^{\star \star \star \star} \\
{[0.0134]}\end{array}$ & $\begin{array}{c}0.00838 \\
{[0.00966]}\end{array}$ & $\begin{array}{c}-0.141^{* \star *} \\
{[0.0138]}\end{array}$ & $\begin{array}{c}-0.144^{\star \star \star} \\
{[0.0159]}\end{array}$ & $\begin{array}{l}0.000910 \\
{[0.00737]}\end{array}$ & $\begin{array}{l}-0.150^{\star \star \star *} \\
{[0.0175]}\end{array}$ \\
\hline $\ln$ (per capita income) & & & & $\begin{array}{c}0.0169^{*} \\
{[0.00904]}\end{array}$ & $\begin{array}{l}0.0109^{* * *} \\
{[0.00329]}\end{array}$ & $\begin{array}{c}0.0111 \\
{[0.00907]}\end{array}$ & & & & $\begin{array}{c}0.0166^{*} \\
{[0.00896]}\end{array}$ & $\begin{array}{l}0.0108^{* * *} \\
{[0.00330]}\end{array}$ & $\begin{array}{c}0.0108 \\
{[0.00899]}\end{array}$ \\
\hline In(occupied) & & & & $\begin{array}{l}0.00710^{\star *} \\
{[0.00350]}\end{array}$ & $\begin{array}{c}0.00106 \\
{[0.00132]}\end{array}$ & $\begin{array}{l}0.00641^{*} \\
{[0.00338]}\end{array}$ & & & & $\begin{array}{l}0.00741^{\star *} \\
{[0.00348]}\end{array}$ & $\begin{array}{c}0.00112 \\
{[0.00132]}\end{array}$ & $\begin{array}{l}0.00670^{\star *} \\
{[0.00335]}\end{array}$ \\
\hline Observations & $4,095,694$ & $4,095,694$ & $3,924,953$ & $4,095,694$ & $4,095,694$ & $3,924,953$ & $4,095,694$ & $4,095,694$ & $3,924,953$ & $4,095,694$ & $4,095,694$ & $3,924,953$ \\
\hline R-squared & 0.068 & 0.063 & 0.048 & 0.068 & 0.063 & 0.048 & 0.068 & 0.063 & 0.049 & 0.069 & 0.063 & 0.049 \\
\hline
\end{tabular}

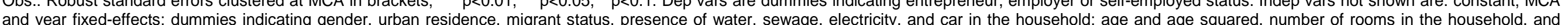

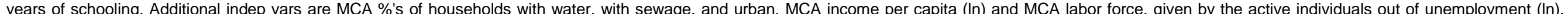
Census data (restricted to ages btwn 25 and 50). 
Table 5: Effect of SCT on Entrepreneurship - OLS Results, Distance to closest SCT - MCAs in the state of São Paulo, Brazil - 1970-2000

\begin{tabular}{|c|c|c|c|c|c|c|c|c|c|c|c|c|}
\hline \multirow[b]{3}{*}{ Vars } & \multicolumn{6}{|c|}{ Smooth decay } & \multicolumn{6}{|c|}{$30 \mathrm{~km}$ radius } \\
\hline & (1) & $(2)$ & (3) & (4) & $(5)$ & (6) & (7) & $(8)$ & (9) & (10) & $(11)$ & (12) \\
\hline & ent & emp & self & ent & emp & self & ent & emp & self & ent & emp & self \\
\hline SCT & $\begin{array}{l}0.0450^{* * *} \\
{[0.00846]}\end{array}$ & $\begin{array}{l}0.00461^{* * *} \\
{[0.00159]}\end{array}$ & $\begin{array}{l}0.0436^{* * *} \\
{[0.00860]}\end{array}$ & & & & $\begin{array}{l}0.0940^{* * *} \\
{[0.0248]}\end{array}$ & $\begin{array}{c}0.00559^{*} \\
{[0.00312]}\end{array}$ & $\begin{array}{l}0.0927^{* * *} \\
{[0.0255]}\end{array}$ & & & \\
\hline $\begin{array}{l}\text { SCT below median } \\
\text { schooling }\end{array}$ & & & & $\begin{array}{l}0.0247^{* * *} \\
{[0.00913]}\end{array}$ & $\begin{array}{c}0.00122 \\
{[0.00160]}\end{array}$ & $\begin{array}{l}0.0239^{* * *} \\
{[0.00876]}\end{array}$ & & & & $\begin{array}{l}0.0674^{* * *} \\
{[0.0251]}\end{array}$ & $\begin{array}{c}0.00205 \\
{[0.00308]}\end{array}$ & $\begin{array}{c}0.0667^{\star * *} \\
{[0.0257]}\end{array}$ \\
\hline $\begin{array}{l}\text { SCT above median } \\
\text { schooling }\end{array}$ & & & & $\begin{array}{l}0.0524^{\star * *} \\
{[0.00790]}\end{array}$ & $\begin{array}{c}0.00586^{\star * *} \\
{[0.00184]}\end{array}$ & $\begin{array}{l}0.0512^{* * *} \\
{[0.00813]}\end{array}$ & & & & $\begin{array}{l}0.106^{* * *} \\
{[0.0245]}\end{array}$ & $\begin{array}{l}0.00716^{* *} \\
{[0.00326]}\end{array}$ & $\begin{array}{l}0.105^{\star * *} \\
{[0.0252]}\end{array}$ \\
\hline Observations & $4,095,694$ & $4,095,694$ & $3,924,953$ & $4,095,694$ & $4,095,694$ & $3,924,953$ & $4,095,694$ & $4,095,694$ & $3,924,953$ & $4,095,694$ & $4,095,694$ & $3,924,953$ \\
\hline R-squared & 0.068 & 0.063 & 0.048 & 0.068 & 0.063 & 0.048 & 0.068 & 0.063 & 0.048 & 0.068 & 0.063 & 0.048 \\
\hline
\end{tabular}


Table 6: Effect of SCT on Entrepreneurship - OLS Results, Timing of Effects - MCAs in the state of São Paulo, Brazil - 1970-2000

Panel A: SCC

\begin{tabular}{lccc}
\hline \multirow{2}{*}{ Vars } & $\begin{array}{c}(1) \\
\text { entrepreneur }\end{array}$ & $\begin{array}{c}(2) \\
\text { employer }\end{array}$ & $\begin{array}{c}(3) \\
\text { self-employed }\end{array}$ \\
SCT & & & \\
& $0.0393^{\star * *}$ & $0.00310^{*}$ & $0.0388^{\star * *}$ \\
SCC & {$[0.00871]$} & {$[0.00178]$} & {$[0.00900]$} \\
& $0.00498^{\star *}$ & $-0.00556^{\star * *}$ & $0.00909^{\star \star *}$ \\
Observations & {$[0.00208]$} & {$[0.00170]$} & {$[0.00232]$} \\
R-squared & $4,095,694$ & $4,095,694$ & $3,924,953$ \\
\hline
\end{tabular}

Panel B: SCC and Placebo

\begin{tabular}{|c|c|c|c|}
\hline Vars & $\begin{array}{c}(1) \\
\text { entrepreneur }\end{array}$ & $\begin{array}{c}\text { (2) } \\
\text { employer }\end{array}$ & $\begin{array}{c}\text { (3) } \\
\text { self-employed }\end{array}$ \\
\hline SCT & $\begin{array}{l}0.0402^{\star \star *} \\
{[0.00848]}\end{array}$ & $\begin{array}{l}0.00441^{* *} \\
{[0.00184]}\end{array}$ & $\begin{array}{l}0.0384^{\star * *} \\
{[0.00848]}\end{array}$ \\
\hline SCC & $\begin{array}{c}0.00694 \\
{[0.00727]}\end{array}$ & $\begin{array}{l}-0.00258 \\
{[0.00265]}\end{array}$ & $\begin{array}{c}0.00822 \\
{[0.00619]}\end{array}$ \\
\hline placebo & $\begin{array}{c}0.00151 \\
{[0.00528]}\end{array}$ & $\begin{array}{l}0.00230^{\star *} \\
{[0.00103]}\end{array}$ & $\begin{array}{l}-0.000672 \\
{[0.00512]}\end{array}$ \\
\hline $\begin{array}{l}\text { Observations } \\
\text { R-squared }\end{array}$ & $\begin{array}{c}4,095,694 \\
0.068\end{array}$ & $\begin{array}{c}4,095,694 \\
0.063\end{array}$ & $\begin{array}{c}3,924,953 \\
0.048\end{array}$ \\
\hline
\end{tabular}

Panel C: Restricted Sample (1991-2000)

\begin{tabular}{lccc}
\hline Vars & $\begin{array}{c}(1) \\
\text { entrepreneur }\end{array}$ & $\begin{array}{c}(2) \\
\text { employer }\end{array}$ & $\begin{array}{c}(3) \\
\text { self-employed }\end{array}$ \\
\hline SCT & & & \\
& $0.0155^{\star * *}$ & $0.00504^{* *}$ & $0.0126^{\star *}$ \\
& {$[0.00561]$} & {$[0.00228]$} & {$[0.00495]$} \\
Observations & & & \\
R-squared & $1,757,899$ & $1,757,899$ & $1,674,621$ \\
& 0.061 & 0.065 & 0.040 \\
\hline
\end{tabular}

Obs.: Robust standard errors clustered at MCA in brackets; ${ }^{* *} p<0.01,{ }^{* *} p<0.05,{ }^{*} p<0.1$. Dep vars are dummies indicating entrepreneur, employer or self-employed status. Indep vars not shown are: constant; MCA and year fixed-effects; dummies indicating gender, urban residence, migrant status, presence of water, sewage, electricity, and car in the household; age and age squared, number of rooms in the household, and years of schooling. Additional indep vars are dummies of SCC presence and placebo dummies indicating observation before SCT implementation (or before SCC implementation in MCAs where these were in place). Census data (restricted to ages btwn 25 and 50). 
Table 7: Effect of SCT on Entrepreneurship - IV Results - MCAs in the state of São Paulo, Brazil - 1970-2000

Panel A: First Stage

(1) (2)

Vars SCT as dep. var.

\begin{tabular}{lcc} 
SCT & $0.580^{* * *}$ & $0.534^{* * *}$ \\
& {$[0.0592]$} & {$[0.0619]$} \\
Indiv. Controls & $X$ & $X$ \\
Agg. Controls & & $X$ \\
& & \\
Observations & $4,095,694$ & $4,095,694$ \\
F of Inst & 95.90 & 74.60 \\
[p-value] & {$[0.00]$} & {$[0.00]$} \\
\hline
\end{tabular}

Panel B: Second Stage

\begin{tabular}{|c|c|c|c|c|c|c|}
\hline Vars & $\begin{array}{c}\text { (1) } \\
\text { entrepreneur }\end{array}$ & $\begin{array}{c}(2) \\
\text { employer }\end{array}$ & $\begin{array}{c}(3) \\
\text { self-employed }\end{array}$ & $\begin{array}{c}(4) \\
\text { entrepreneur }\end{array}$ & $\begin{array}{c}(5) \\
\text { employer }\end{array}$ & $\begin{array}{c}(6) \\
\text { self-employed }\end{array}$ \\
\hline SCT & $\begin{array}{l}0.0219^{\star * *} \\
{[0.00708]}\end{array}$ & $\begin{array}{l}0.00565^{\star *} \\
{[0.00254]}\end{array}$ & $\begin{array}{l}0.0200^{\star \star *} \\
{[0.00724]}\end{array}$ & $\begin{array}{l}0.0198^{* * *} \\
{[0.00724]}\end{array}$ & $\begin{array}{c}0.00365 \\
{[0.00264]}\end{array}$ & $\begin{array}{c}0.0182^{* *} \\
{[0.00756]}\end{array}$ \\
\hline Indiv. Controls & $x$ & $x$ & $x$ & $x$ & $x$ & $x$ \\
\hline Agg. Controls & & & & $x$ & $x$ & $x$ \\
\hline Observations & $4.095,694$ & $4.095,694$ & 3.924 .953 & $4.095,694$ & $4.095,694$ & 3.924 .953 \\
\hline
\end{tabular}

Obs.: Robust standard errors clustered at MCA in brackets; ${ }^{* *} p<0.01,{ }^{* *} p<0.05,{ }^{*} p<0.1$. In Panel A, dep. var. is dummy indicating presence of an SCT. In Panel B, dep vars are dummies indicating entrepreneur, employer or self-employed status. Indep vars not shown are: constant; MCA and year fixed-effects; individual level controls (dummies indicating gender, urban residence, migrant status, presence of water, sewage, electricity, and car in the household; age and age squared, number of rooms in the household, years of schooling), and MCA agg. controls (\% of households with water, with sewage, and urban, income per capita and labor force). Census data (restricted to ages btwn 25 and 50). 
Table 8: Effect of SCT on Entrepreneurship - OLS Results, Mechanisms - MCAs in the state of São Paulo, Brazil $1970-2000$

Panel A: Credit

\begin{tabular}{|c|c|c|c|}
\hline Vars & $\begin{array}{l}(1) \\
\text { ent }\end{array}$ & $\begin{array}{l}(2) \\
\text { emp }\end{array}$ & $\begin{array}{l}(3) \\
\text { self }\end{array}$ \\
\hline SCT & $\begin{array}{c}-0.0212^{\star \star} \\
{[0.0107]}\end{array}$ & $\begin{array}{l}0.00779^{\star *} \\
{[0.00307]}\end{array}$ & $\begin{array}{c}-0.0289^{* * *} \\
{[0.0106]}\end{array}$ \\
\hline SCT*In(per capita credit) & $\begin{array}{l}0.00779^{* * *} \\
{[0.000860]}\end{array}$ & $\begin{array}{c}-0.000524 \\
{[0.000367]}\end{array}$ & $\begin{array}{l}0.00867^{* * *} \\
{[0.000888]}\end{array}$ \\
\hline Constant & $\begin{array}{l}-0.357^{\star * \star} \\
{[0.0154]}\end{array}$ & $\begin{array}{l}-0.174^{\star \star *} \\
{[0.00468]}\end{array}$ & $\begin{array}{l}-0.229^{\star \star \star} \\
{[0.0124]}\end{array}$ \\
\hline $\begin{array}{l}\text { Observations } \\
\text { R-squared }\end{array}$ & $\begin{array}{c}4,086,627 \\
0.068 \\
\end{array}$ & $\begin{array}{c}4,086,627 \\
0.063 \\
\end{array}$ & $\begin{array}{c}3,916,143 \\
0.048\end{array}$ \\
\hline \multicolumn{4}{|l|}{ Panel B: Share of capital-intensive activities in 1991} \\
\hline Vars & $\begin{array}{l}(1) \\
\text { ent }\end{array}$ & $\begin{array}{l}(2) \\
\text { emp }\end{array}$ & $\begin{array}{l}(3) \\
\text { self }\end{array}$ \\
\hline SCT & $\begin{array}{c}-0.0747^{* * *} \\
{[0.0151]}\end{array}$ & $\begin{array}{l}0.00990^{\star *} \\
{[0.00444]}\end{array}$ & $\begin{array}{c}-0.0866^{\star * *} \\
{[0.0160]}\end{array}$ \\
\hline SCT $^{*}$ share of ent. in capital-intensive active. 1991 & $\begin{array}{l}0.309^{* * *} \\
{[0.0348]}\end{array}$ & $\begin{array}{l}-0.0162 \\
{[0.0118]}\end{array}$ & $\begin{array}{l}0.338^{* * *} \\
{[0.0391]}\end{array}$ \\
\hline Constant & $\begin{array}{l}-0.357^{* * *} \\
{[0.0152]}\end{array}$ & $\begin{array}{l}-0.174^{* *} \\
{[0.00467]}\end{array}$ & $\begin{array}{c}-0.229^{\star * *} \\
{[0.0122]}\end{array}$ \\
\hline $\begin{array}{l}\text { Observations } \\
\text { R-squared }\end{array}$ & $\begin{array}{c}4,095,694 \\
0.068\end{array}$ & $\begin{array}{c}4,095,694 \\
0.063 \\
\end{array}$ & $\begin{array}{c}3,924,953 \\
0.048\end{array}$ \\
\hline
\end{tabular}

Panel C: Capital-intensive activities in 2000

\begin{tabular}{|c|c|c|c|}
\hline Vars & $\begin{array}{l}(1) \\
\text { ent }\end{array}$ & $\begin{array}{l}(2) \\
\text { emp }\end{array}$ & $\begin{array}{l}(3) \\
\text { self }\end{array}$ \\
\hline SCT*$^{*}$ (1-capital_intensive) & $\begin{array}{l}0.0237^{* * *} \\
{[0.00696]}\end{array}$ & $\begin{array}{l}0.00397^{\star *} \\
{[0.00170]}\end{array}$ & $\begin{array}{l}0.0218^{* * *} \\
{[0.00639]}\end{array}$ \\
\hline SCT*capital_intensive & $\begin{array}{l}0.0525^{\star \star \star} \\
{[0.00935]}\end{array}$ & $\begin{array}{l}0.00566^{* *} \\
{[0.00223]}\end{array}$ & $\begin{array}{c}0.0511^{* * *} \\
{[0.0106]}\end{array}$ \\
\hline capital_intensive & $\begin{array}{l}-0.0774^{* * *} \\
{[0.00490]}\end{array}$ & $\begin{array}{l}0.0116^{\star * *} \\
{[0.00243]}\end{array}$ & $\begin{array}{l}-0.0902^{* * *} \\
{[0.00437]}\end{array}$ \\
\hline Constant & $\begin{array}{l}-0.343^{\star \star \star} \\
{[0.0347]}\end{array}$ & $\begin{array}{l}-0.186^{\star * \star} \\
{[0.0174]}\end{array}$ & $\begin{array}{l}-0.204^{\star \star *} \\
{[0.0340]}\end{array}$ \\
\hline $\begin{array}{l}\text { Observations } \\
\text { R-squared }\end{array}$ & $\begin{array}{c}4,095,694 \\
0.074\end{array}$ & $\begin{array}{c}4,095,694 \\
0.064\end{array}$ & $\begin{array}{c}3,924,953 \\
0.057\end{array}$ \\
\hline
\end{tabular}

Obs.: Robust standard errors clustered at MCA in brackets; ${ }^{* *} p<0.01,{ }^{* *} p<0.05,{ }^{*} p<0.1$. Dep vars are dummies indicating entrepreneur, employer or self-employed status. Indep vars not shown are: constant; MCA and year fixed-effects; dummies indicating gender, urban residence, migrant status, presence of water, sewage, electricity, and car in the household; age and age squared, number of rooms in the household, years of schooling, MCA's income per capita (In), and additionally in Panels B and C, MCA's number of occupied individuals (In) and sector's (capital intensive) number of occupied individuals (In). Additional indep vars are, in Panel A, interactions of SCT presence with per capita credit (In) in 1997, in Panel B, with the share of entrepreneurs in capital-intensive activities in 1991 (\%), and in Panel C, with an indicator of whether the individual is an employer or entrepreneur in capital intensive activities. Capital-intensive industries are those linked to transformation industry, commerce, transport and communication. Census data (restricted to ages btwn 25 and 50). 
Figure 1(a): Net effect of SCT on entrepreneurship by decile of In(per capita credit) in 1997

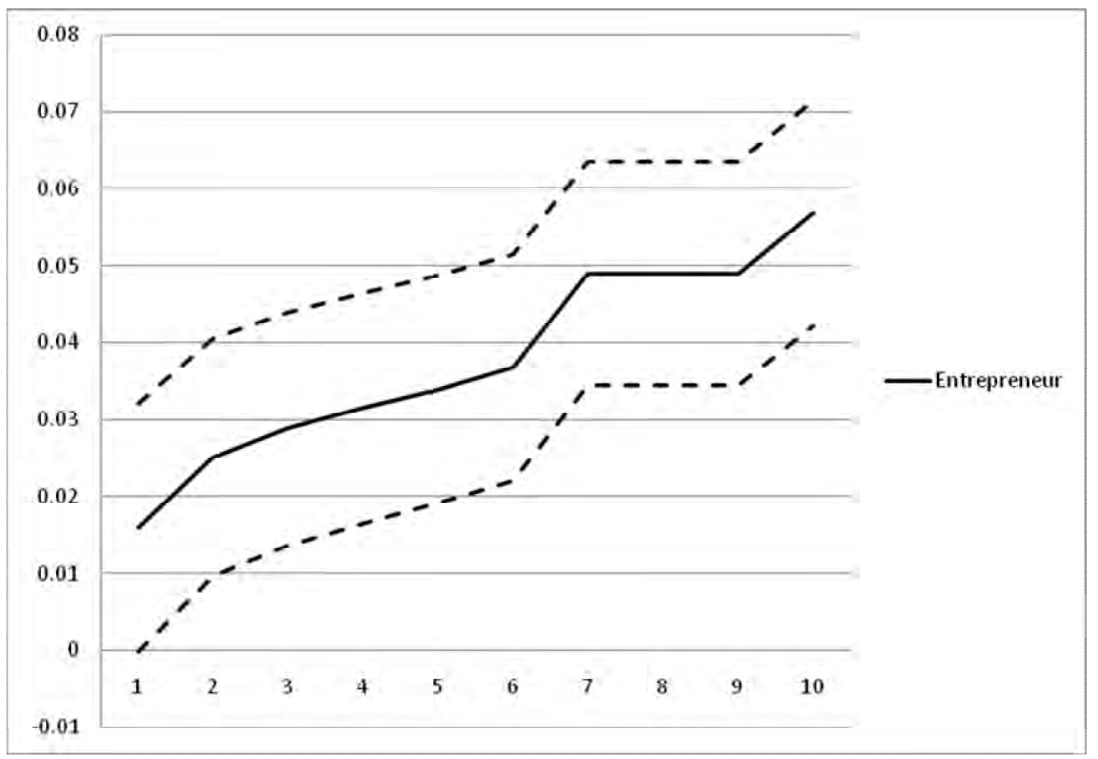

Obs.: Net effects by decile and confidence intervals at the $5 \%$ significance level are calculated using the results in Panel A of Table 8 and the average by decile of In(per capita credit) in 1997.

Figure 1(b): Net effect of SCT on entrepreneurship by decile of \% entrep. in capital-intensive activities in 1991

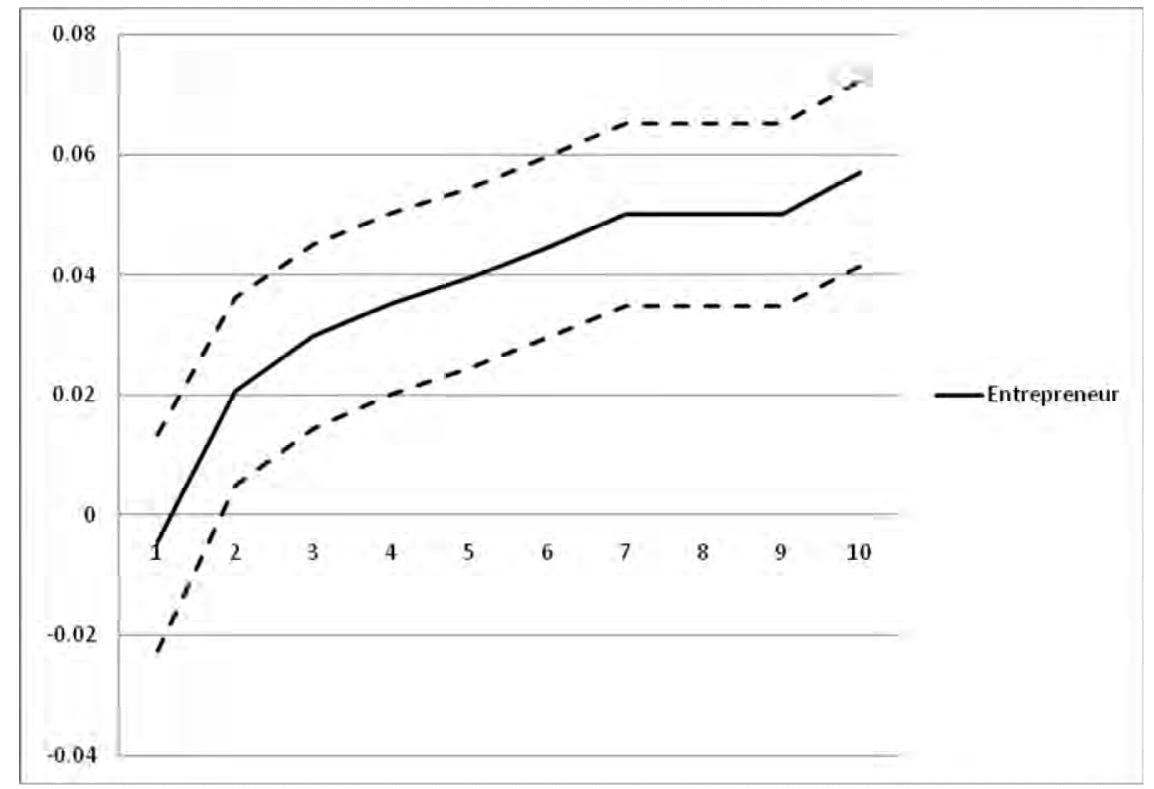

Obs.: Net effects by decile and confidence intervals at the $5 \%$ significance level are calculated using the results in Panel B of Table 8 and the average by decile of \% entrepreneurs in capital-intensive activities in 1991. 


\section{Appendix A: Distribution of Activities}

Table A.1 - Distribution of Self-Employed and Employers by Activity - Brazil - 2000

\begin{tabular}{|c|c|c|c|c|c|}
\hline \multicolumn{3}{|l|}{ Self-Employed } & \multicolumn{3}{|l|}{ Employer } \\
\hline Activity & Percent & Cumulative & Activity & Percent & Cumulative \\
\hline Other or undefined & 18.74 & 18.74 & Other or undefined & 13.31 & 13.31 \\
\hline Food catering services & 7.93 & 41.51 & Commerce of food and beverages & 6.8 & 28.94 \\
\hline Informal commerce & 6.98 & 48.49 & Civil construction industry & 4.09 & 33.03 \\
\hline Personal hygiene services & 4.72 & 53.21 & Commerce of clothing & 3.99 & 37.02 \\
\hline Road transport of cargo & 3.58 & 60.38 & Repair and maintenance of vehicles & 3.2 & 43.8 \\
\hline Commerce of food and beverages & 3.27 & 63.65 & Commerce of vehicles and accessories & 2.63 & 46.43 \\
\hline Repair and maintenance of vehicles & 2.87 & 66.52 & Private medical services & 2.32 & 48.75 \\
\hline Clothing industry & 2.66 & 69.18 & $\begin{array}{l}\text { Commerce of machinery and electrical } \\
\text { material }\end{array}$ & 2.28 & 51.03 \\
\hline Cattle-raising & 1.02 & 76.7 & $\begin{array}{l}\text { Commerce of chemical and } \\
\text { pharmaceutical products }\end{array}$ & 2.06 & 61.79 \\
\hline Furniture industry & 1.00 & 77.7 & Accounting and auditing & 1.95 & 63.74 \\
\hline Commerce of clothing & 0.98 & 78.68 & Food industry & 1.76 & 65.5 \\
\hline Horticulture and floriculture & 0.95 & 79.63 & Road transport of cargo & 1.54 & 67.04 \\
\hline \multirow[t]{6}{*}{ Cleaning and building conservation services } & 0.95 & 80.58 & Private teaching & 1.34 & 68.38 \\
\hline & & & Consulting services & 1.26 & 69.64 \\
\hline & & & Commerce of fuel and lubricant & 1.19 & 70.83 \\
\hline & & & Editorial industry & 1.15 & 71.98 \\
\hline & & & Furniture industry & 1.06 & 73.04 \\
\hline & & & Informal commerce & 1.01 & 74.05 \\
\hline
\end{tabular}

Obs.: 2000 census data. 


\section{Appendix B: Creation of Variables across Censuses}

Since Brazilian censuses' questionnaires change every survey year, variables were built so as to guarantee consistency over time. In particular, the indicators of access to water and electricity supply and sewage collection denote whether the household has access to the general distribution network. The variable indicating migrant status is that of whether the individual has always lived on that municipality.

For schooling, matching categories over time is not straightforward because the classification for elementary and high school changed in Brazil between 1970 and 1980. In the latter censuses, both the old and new classification systems coexist, but not in the earlier ones. Nonetheless, once accounting for the classification system, inputting schooling years is clearcut.

Lastly, dependent variables always reflect individuals' position in their main occupation.

The specific census questions used in our analysis and the coding of our variables are described in detail in the tables below.

Table B.1 - Definition of Independent Variables by Year - Census Codes

\begin{tabular}{c|c|c|c|c}
\hline Variable & 1970 & 1980 & 1991 & 2000 \\
\hline male & VAR23 $=0$ & V501 =1 & V0301 =1 & V0401=1 \\
\hline age & VAR27 & V606 & V3072 & V4752 \\
\hline urban & VAR4 $=0$ or 1 & V598 $=0$ & V1061 $=1$ or 3 & V1006 $=1$ \\
\hline water & VAR12 $=1$ or 2 & V206 $=1$ or 6 & V0205 $=1$ or 4 & V0207 $=1$ \\
\hline sewage & VAR13 $=1$ & V207 $=2$ & V0206 $=1$ & V0211 1 \\
\hline electricity & VAR14 $=1$ & V217 $=2$ or 4 & V0221 $=1$ or 2 & V0213 $=1$ \\
\hline car & VAR19 & V221 & V0218 & V0222 \\
\hline rooms & VAR20 & V212 & V0211 & V0203 \\
\hline migrant & VAR32 $<8$ & V513 $=8$ & V0314 $=2$ or 3 & V0415 $=2$ \\
\hline
\end{tabular}

Table B.2 - Definition of Dependent Variables by Year - Census Codes

\begin{tabular}{|c|c|}
\hline $\begin{array}{l}\frac{1970}{\text { employer }=1 \text { if VAR } 46=5} \\
\text { self-employed = } 1 \text { if VAR } 46=3 \\
\text { entrepreneur = employer + self-employed. }\end{array}$ & $\begin{array}{l}\frac{1980}{\text { employer }=1 \text { if VAR533 }=7} \\
\text { self-employed }=1 \text { if VAR533 = } \\
\text { entrepreneur }=\text { employer }+ \text { self-employed }\end{array}$ \\
\hline $\begin{array}{l}\frac{1991}{\text { employer }=1 \text { if VAR0349 = } 10} \\
\text { self-employed = } 1 \text { if VAR0349=9; } \\
\text { entrepreneur = employer + self-employed. }\end{array}$ & $\begin{array}{l}2000 \\
\text { employer = } 1 \text { if VAR0447 = } 5 \\
\text { self-employed = } 1 \text { if VAR0 } 447=6 \\
\text { entrepreneur = employer + self-employed. }\end{array}$ \\
\hline
\end{tabular}


Table B.3 - Definition of Schooling Variable by Year - Census Codes

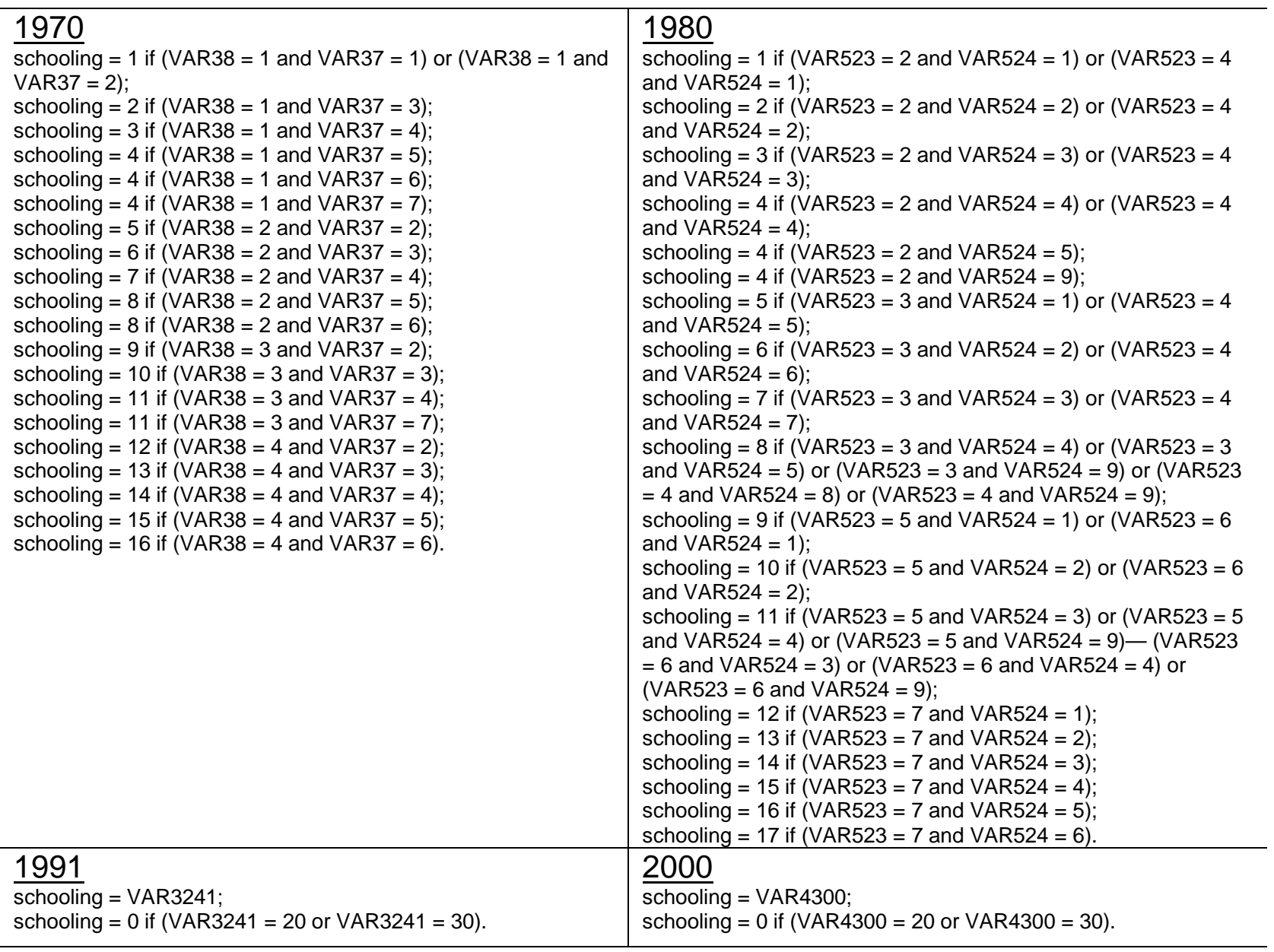


Appendix C: Definition of Capital Intensive Sectors

Table C.I - Definition of capital-intensive activities in Censuses 1970-2000

\begin{tabular}{|c|c|c|c|c|}
\hline \multicolumn{5}{|c|}{ Non-capital-intensive sectors } \\
\hline Activity & 1970 & 1980 & 1991 & 2000 \\
\hline $\begin{array}{l}\text { Agriculture, fishery and } \\
\text { vegetal extraction }\end{array}$ & VAR45 $=111-306$ & $V 532=11-58$ & V3461 = 1 & $V 4462=11-42$ \\
\hline Civil construction & VAR45 $=341-342$ & $V 532=340$ & V3461 = 3 & $V 4462=340$ \\
\hline $\begin{array}{l}\text { Other industrial activities (mineral } \\
\text { extraction and industrial services } \\
\text { of public utility) }\end{array}$ & VAR45 = 351-352 & $V 532=351-354$ & $V 3461=4$ & $\begin{array}{l}\text { V4462 }=50-59 \\
\quad 351-354\end{array}$ \\
\hline $\begin{array}{c}\text { Auxiliary services to the economic } \\
\text { activity (technical-professional and } \\
\text { auxiliary) }\end{array}$ & VAR45 = 921-928 & V532 = 571-589 & $\mathrm{V} 3461=7$ & $V 4462=571-589$ \\
\hline $\begin{array}{l}\text { Personal services (lodging and } \\
\text { food catering, maintenance and } \\
\text { conservation, personal, to } \\
\text { households, and entertainment) }\end{array}$ & VAR45 $=511-518$ & $V 532=511-552$ & $\mathrm{~V} 3461=8$ & V4462 $=511-552$ \\
\hline $\begin{array}{l}\text { Social (social, medical, dentistry, } \\
\text { and teaching) }\end{array}$ & VAR45 = 711-721 & V532 $=610-632$ & $\mathrm{~V} 3461=9$ & $V 4462=610-632$ \\
\hline Public administration & VAR45 $=811-827$ & V532 = 711-727 & $\begin{array}{c}\mathrm{V} 3461= \\
10\end{array}$ & V4462 $=711-727$ \\
\hline Other activities & $\begin{array}{c}\text { VAR45 = 911-916 } \\
931-934\end{array}$ & $\begin{array}{l}V 532=451-464 \\
\quad 801-902\end{array}$ & $\begin{array}{c}\mathrm{V} 3461= \\
11\end{array}$ & $\begin{array}{c}V 4462=451-464 \\
801-903\end{array}$ \\
\hline \multicolumn{5}{|c|}{ Capital-intensive sectors } \\
\hline Activity & 1970 & 1980 & 1991 & 2000 \\
\hline $\begin{array}{l}\text { Transformation } \\
\text { industry }\end{array}$ & VAR45 = 311-334 & V532 $=100-290$ & $V 3461=2$ & V4462 $=100-300$ \\
\hline Commerce & VAR45 $=411-424$ & $V 532=410-423$ & $V 3461=5$ & $V 4462=410-424$ \\
\hline $\begin{array}{l}\text { Transports and } \\
\text { communication }\end{array}$ & VAR45 $=611-620$ & $V 532=471-482$ & V3461 = 6 & V4462 $=471-482$ \\
\hline
\end{tabular}

